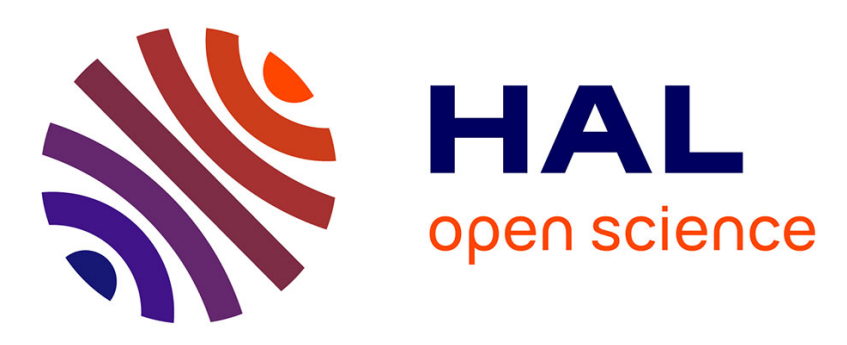

\title{
Strain Localization Within a Syntectonic Intrusion in a Back-Arc Extensional Context: The Naxos Monzogranite (Greece)
}

Eloïse Bessière, Aurélien Rabillard, Jacques Précigout, Laurent Arbaret, Laurent Jolivet, Romain Augier, Armel Menant, Nicolas Mansard

\section{To cite this version:}

Eloïse Bessière, Aurélien Rabillard, Jacques Précigout, Laurent Arbaret, Laurent Jolivet, et al.. Strain Localization Within a Syntectonic Intrusion in a Back-Arc Extensional Context: The Naxos Monzogranite (Greece). Tectonics, 2018, 37 (2), pp.558-587. 10.1002/2017TC004801 . insu-01680181

\section{HAL Id: insu-01680181 https://hal-insu.archives-ouvertes.fr/insu-01680181}

Submitted on 28 Feb 2018

HAL is a multi-disciplinary open access archive for the deposit and dissemination of scientific research documents, whether they are published or not. The documents may come from teaching and research institutions in France or abroad, or from public or private research centers.
L'archive ouverte pluridisciplinaire HAL, est destinée au dépôt et à la diffusion de documents scientifiques de niveau recherche, publiés ou non, émanant des établissements d'enseignement et de recherche français ou étrangers, des laboratoires publics ou privés. 


\section{Tectonics}

\section{RESEARCH ARTICLE}

10.1002/2017TC004801

Key Points:

- In this paper, we discuss the strain localization within a pluton in a subsolidus system and in an extensional context

- We used a multiscale approach based on a field study and quantitative analysis (characterization of SPO, quartz LPO, and 3-D visualization) - Our results show a very good correlation between macroscopic (from field observations) and microscopic (from laboratory analysis) scales

Correspondence to:

E. Bessiere,

eloise.bessiere@cnrs-orleans.fr

\section{Citation:}

Bessiere, E., Rabillard, A., Précigout, J., Arbaret, L., Jolivet, L., Augier, R., ... Mansard, N. (2018). Strain localization within a syntectonic intrusion in a backarc extensional context: The Naxos monzogranite (Greece). Tectonics, 37. https://doi.org/10.1002/2017TC004801

Received 7 SEP 2017 Accepted 23 DEC 2017 Accepted article online 6 JAN 2018

\section{Strain Localization Within a Syntectonic Intrusion in a Back-Arc Extensional Context: The Naxos Monzogranite (Greece)}

\author{
Eloïse Bessiere $^{1,2,3}$ iD, Aurelien Rabillard 1,2,3 iD, Jacques Précigout 1,2,3 ${ }^{\text {, Laurent Arbaret }}{ }^{1,2,3}$ iD, \\ Laurent Jolivet $^{1,2,3,4}$ iD, Romain Augier ${ }^{1,2,3}$, Armel Menant 1,2,3,5, and Nicolas Mansard ${ }^{1,2,3}$ iD \\ ${ }^{1}$ Université d'Orléans, ISTO, UMR 7327, Orléans, France, ${ }^{2}$ CNRS/INSU, ISTO, UMR 7327, Orléans, France, ${ }^{3}$ BRGM, ISTO, UMR \\ 7327, Orléans, France, ${ }^{4}$ Now at Sorbonne University, CNRS-INSU, Institut des Sciences de la Terre Paris, ISTeP UMR 7193, Paris, \\ France, ${ }^{5}$ Now at Institut de Physique du Globe de Paris, Paris Sorbonne Cité, University Diderot, UMR 7154, Paris, France
}

Abstract Although fundamental to the understanding of crustal dynamics in extensional setting, the relationships between the emplacement of granitic intrusions and activity of detachments still remain very elusive. Through a multiscale approach, we here document a continuous deformation history between the monzogranitic intrusion of Naxos and the Naxos-Paros Detachment System (Cyclades, Greece). Field observations first show an early magmatic deformation followed by solid-state, ductile, and then brittle deformation when approaching the detachment zone, as evidenced by the overprinting of mylonites by cataclastes and pseudotachylites. From these observations, we define six strain facies that characterize a positive strain gradient from core to rim of the Naxos monzogranite. Based on field pictures, X-ray tomography, and electron backscatter diffraction (EBSD) analyses along the strain gradient, we then quantify the intensity of mineralogical fabrics in 2-D and 3-D and better characterize the deformation mechanisms. Our measured shape variations of the strain ellipsoid corroborate the large-scale strain gradient, showing a good correlation between qualitative and quantitative studies. In addition, EBSD data indicate that dislocation creep was predominant during cooling from more than $500^{\circ} \mathrm{C}$ to temperature conditions of the ductile-to-brittle transition. However, (1) a weakening of quartz lattice preferred orientation with increasing strain and (2) evidence of numerous four-grain junctions in high-strain shear bands also indicate that grain boundary sliding significantly contributed to the deformation. Although the source of grain boundary sliding remains to be constrained, it provides a consistent approach to account for strain localization in Naxos.

\section{Introduction}

During the last 30 years, several studies have been devoted to the strain localization problematic linked with the interactions between plutonic activity and shear zones development in extensional (e.g., Baldwin et al., 1993), transtensional (e.g., Hutton, 1982), or transpressional tectonic settings (e.g., McCaffrey, 1992). In extensional continental regions, especially where "Metamorphic Core Complexes" (MCCs) form, the nucleation and ensuing development of shear zones within the continental crust are often coeval with the crystallization of granitoid intrusions. MCCs are crustal-scale structures that develop during the thinning of a previously thickened crust in an extensional postorogenic context (Coney \& Harms, 1984; Lister \& Davis, 1989). MCCs are inherently characterized by a low-angle normal fault or detachment fault, separating a slightly or nonmetamorphosed upper unit, from a lower unit with a higher metamorphic grade, frequently but not systematically associated with partial melting (see recent review of Platt et al., 2015). Field and thermochronological studies have identified close spatiotemporal relationships between plutonic activity and MCCs development, as in the Basin and Range (Crittenden et al., 1980; Davis et al., 1993; Gans et al., 1989; Wernicke et al., 1987), the Mediterranean region (Acocella \& Rossetti, 2002; Daniel \& Jolivet, 1995; Jolivet et al., 1998; Smith et al., 2011), and more recently in East Asia (Charles et al., 2011, 2013). These correlations have been especially documented in the Cyclades (Aegean Sea, Greece) (Brichau et al., 2007; Denèle et al., 2011; Faure et al., 1991; Kokkalas \& Aydin, 2013; Koukouvelas \& Kokkalas, 2003; Kumerics et al., 2005; Laurent et al., 2015; Lee \& Lister, 1992; Rabillard et al., 2015; Tschegg \& Grasemann, 2009).

Two opposing models were used to explain these spatiotemporal interactions. On the one hand, it was often suggested that active or preexisting shear zones serve as upward drains for magma transfer as well as mechanical boundaries for magma storage (Brown, 1994; D'Lemos et al. 1992; Tikoff \& Teyssier, 1992; Vigneresse, 1995a, 1995b). On the other hand, partially crystallized magmatic bodies constitute weak 
rheological heterogeneities, localizing shear zones that propagate in the host rocks (Davidson et al., 1994; Lister \& Baldwin, 1993; Tommasi et al., 1994).

To better constrain interrelations between strain localization processes and plutonic activity during MCCs development, detailed structural field studies are required. The Cyclades appears as an ideal natural laboratory as major extensional shear zones (i.e., the detachments), metamorphic domes, and plutonic intrusions were described as contemporaneous. Recent surveys have been already conducted in this area, in Serifos, Mykonos, and Ikaria Islands (Denèle et al., 2011; Laurent et al., 2015; Rabillard et al., 2015). Study of syntectonic granitoids have thus shown progressive ductile-then-brittle strain localization starting with shear zones nucleation during their cooling and followed by the development of a large-scale strain gradient after complete crystallization toward the upper tectonic contact between the intrusion and enclosing rocks. These observations combined with the overall asymmetrical architecture of the intrusions thus suggest that their emplacement was entirely controlled by active detachments. In recent studies, it has been also demonstrated a control of the intrusions on the detachments activity, gradually inactivating preexisting detachments and forcing their migration structurally upward in the crust (Laurent et al., 2015; Rabillard et al., 2015).

Although the Naxos metamorphic dome was the first MCC described in the Cyclades (Lister et al., 1984), there is no detailed study on the strain localization within the intrusion associated and lately emplaced within this MCC. To achieve this goal, this paper presents two approaches, one qualitative, with field observations over the whole intrusion together with a mapping of the intensity of the shearing deformation, and one involving quantification of strain with a 3-D study of the rock shape fabrics based on image analysis, X-ray tomography, and electron backscatter diffraction (EBSD) measurements.

\section{Geological and Geodynamic Setting}

\subsection{Geological Evolution of the Aegean Region}

The present-day architecture of the Aegean region (Figure 1a), corresponding to the collapsed central part of the Hellenides-Tauride chain, results from a complex tectonic history that can be summarized as a twostepped evolution: (1) an episode of crustal thickening resulting from the successive subduction of the Tethyan oceanic and Apulian continental lithospheres beneath the Eurasian plate during the Eocene (Bonneau \& Kienast, 1982; Van Hinsbergen et al., 2005), followed by (2) a postorogenic collapse of the chain, forming a back-arc basin as a result of the retreat of the African slab operating since the end of the Eocene with an acceleration after 35 Ma (Jolivet \& Brun, 2010; Jolivet \& Faccenna, 2000) or later (23-19 Ma) according to Ring et al. (2010).

Located in the central part of the Aegean domain, the Cyclades consists in series of MCCs where the deepest parts of the Hellenides-Taurides chain were exhumed owing to postorogenic extension. Classically, three main units are distinguished in the Cyclades (Bonneau, 1984; Jolivet et al., 2004; Van Hinsbergen et al., 2005).

1. The Cycladic Continental Basement (CCB) composed of orthogneisses, paragneisses, and micaschists of Paleozoic age (Andriessen et al., 1987; Henjes-Kunst \& Kreuzer, 1982; Keay \& Lister, 2002). It crops out on Naxos, Paros, los, Serifos, or Sikinos Islands (Andriessen et al., 1987; Augier et al., 2015; Grasemann \& Petrakakis, 2007; Huet et al., 2009).

2. The Cycladic Blueschists Unit (CBU) is characterized by a sequence of metapelites, marbles, quartzites, and mafic rocks (meta-gabbro and meta-basalts) and equilibrated in the eclogites or blueschists facies conditions during subduction (Blake et al., 1981a, 1981b; Bonneau \& Kienast, 1982).

3. The Upper Cycladic Unit (UCU) is a complex assemblage of low-metamorphic grade tectonic units resting at the top of the nappe stack from the northern Cyclades all the way to Crete (Asteroussia Nappe). This unit contains pieces of the Pelagonian basement and its nonmetamorphic cover, ophiolitic units related either to a Jurassic or a Cretaceous obduction event, Late Jurassic blueschists, and Miocene sediments deposited during the activity of the Aegean detachments (Bonneau, 1984; Jolivet et al., 2004; Katzir et al., 1996; Maluski et al., 1987; Sanchez-Gomez et al., 2002).

The tectonic history of the Cyclades spans the whole Cenozoic. Age of the high pressure-low temperature ( $\mathrm{HP}$-LT) metamorphism is well documented in the $\mathrm{CBU}$, and radiometric ages associated with the HP-LT metamorphism range between 70 and $35 \mathrm{Ma}$ with the majority of ages grouped in the middle Eocene (50-40 Ma) (Altherr et al., 1979; Bröcker \& Enders, 1999; Maluski et al., 1987; Wijbrans et al., 1990). This HP-LT episode 




Figure 1. Tectonic and geological maps and location of the studied area. (a) Simplified tectonic map of the Aegean region showing the main structures: The North Cycladic Detachment System (NCDS), the West Cycladic Detachment System (WCDS), and the location of Cyclades archipelago. (b) Tectonic map of the Cyclades archipelago showing the main structures, the main metamorphic core complexes and intrusions, and kinematic indicators with the location of Naxos-Paros Islands, modified after Jolivet et al. (2015). (c) Geological map of Naxos and Paros islands, modified after Gautier et al. (1993) and Siebenaller (2008).

corresponds to the burial and the syn-orogenic exhumation of the CBU and CCB within the Hellenic subduction channel (Brun \& Faccenna, 2008; Jolivet et al., 2003; Jolivet \& Brun, 2010; Ring et al., 2010). A second episode is associated with medium pressure-medium to high-temperature (MP-MT/HT) metamorphism in the conditions of the greenschist and more locally of the amphibolite facies, affecting the two lowest units of the Cyclades in the Oligo-Miocene (Altherr et al., 1982). During the lithospheric thinning of the Aegean area, postorogenic extension led to the reworking of the nappe stack by low-angle normal faults and the exhumation of MCCs under crustal-scale detachment systems (Buick, 1991a, 1991ab; Faure et al., 1991; Gautier, Brun, \& Jolivet, 1993; Gautier \& Brun, 1994a, 1994b; Lister et al., 1984; Urai et al., 1990) including the North Cycladic Detachment System (NCDS) (Jolivet et al., 2010; Lecomte et al., 2010; Menant et al., 2013), the Naxos-Paros Detachment System (Bargnesi et al., 2013; Brichau et al., 2006; Gautier et al., 1993), and the West Cycladic Detachment System (WCDS) (Grasemann et al., 2012; Grasemann \& Petrakakis, 2007; Iglseder et al., 2011) (Figures 1a and 1b). Coevally with the activity of these detachments systems, S- and I-type granitoids were intruded in the Aegean crust between 15 and 9 Ma (Brichau et al., 2007, 2008; Bolhar et al., 2010; Iglseder et al., 2009; Keay et al., 2001), such as on the islands of Tinos, Mykonos-Delos-Rhenia, Serifos, Ikaria, and Naxos. These magmatic bodies are temporally and spatially emplaced in close interaction with Miocene MCCs and their associated detachments (Brichau et al., 2007, 2008, 2010; Denèle et al., 2011; Faure et al., 1991; Grasemann \& Petrakakis, 2007; Koukouvelas \& Kokkalas, 2003; Laurent et al., 2015; Lister \& Baldwin, 1993; Rabillard et al., 2015).

\subsection{Geology of Naxos}

Naxos is the largest island of the Cyclades, located in the center of the archipelago (Figure 1b). The main part of the island is a N-S elongated gneiss dome cored with migmatites (Figure 1c) (Buick, 1991a; Jansen, 1973; Urai et al., 1990; Vanderhaeghe, 2004). Numerous studies have been devoted to the structure of the metamorphic dome (Andriessen et al., 1979; Duchêne et al., 2006; Gautier et al., 1993; Keay et al., 2001; 
Koukouvelas \& Kokkalas, 2003; Kruckenberg et al., 2011; Kuhlemann et al., 2004; Seward et al., 2009; Urai et al., 1990; Wijbrans \& McDougall, 1988) and the overlying UCU that consists in Miocene sandstones, conglomerates, and remnants of ophiolitic rocks (Böger, 1983; Kuhlemann et al., 2004; Seward et al., 2009). Metamorphic units in the dome of Naxos Island are classically attributed to either the CBU or the CCB. They consist in an alternation of metapelitic rocks, metavolcanics, and abundant marbles locally associated with metabauxites (e.g., Feenstra, 1985). The metasediments making the cover of the migmatites contain very little metabasites, and they resemble the cover of the Menderes massif rather than the CBU consisting in an alternation of metabasites, marbles, and metapelites. We thus consider the core of the Naxos metamorphic dome as part of the CCB as in Jolivet et al. (2004) or the Basal Unit of Ring and Layer (2003). Local remnants of blueschist parageneses from the earlier Eocene subduction-related HP-LT episode (Wijbrans \& McDougall, 1988) are preserved in the southern part of the dome (Avigad, 1998; Jansen, 1977) despite the overprint of the high-temperature Oligo-Miocene event. Later, during the formation of the Aegean Sea in back-arc context, the dome underwent a MP-MT/HT event, dated between 20.7 and $16.8 \mathrm{Ma}$ by sensitive high-resolution ion microprobe $\mathrm{U}-\mathrm{Pb}$ on zircons (Keay et al., 2001), resulting in a retrograde metamorphism under greenschist facies to amphibolite facies conditions with a gradient of peak temperature toward the core of the dome where partial melting has been described (Jansen, 1977; Duchêne et al., 2006; Vanderhaeghe, 2004). Final exhumation of all of these units was achieved by the activity of the crustal-scale Naxos-Paros Detachment System (Figure 1c) (Buick, 1991a, 1991b; Gautier et al., 1993; Siebenaller, 2008).

Intrusive bodies cropping out on Naxos can be compositionally separated into S- and I-type granitoids. S-type granitoids are typified by numerous yet small peraluminous leucogranite intrusions with a variable composition in terms of chemistry and mineralogy, involving different protoliths (Pe-Piper et al., 1997).

The western l-type granitoid consists in a voluminous composite intrusion characterized by a hornblendebiotite monzogranite (two feldspars, quartz, biotite, amphibole, titanite, and oxides) in the inner part and a subordinate peripheral granodiorite (Altherr et al., 1982; Altherr \& Siebel, 2002; Jansen, 1973; Keay et al., 2001; Pe-Piper, 2000; Pe-Piper et al., 1997; Wijbrans \& McDougall, 1988). Al-in-hornblende barometer indicates crystallization pressures ranging from 200 to $300 \mathrm{MPa}$ (Cao et al., 2016; Jansen \& Schuiling, 1976). The emplacement of this monzogranitic intrusion was dated at circa 15-14 Ma by U/Pb analyses on zircon. Subsequent cooling occurred quite fast between $\sim 13.6$ and $\sim 11$ Ma as constrained by K-Ar and Ar-Ar on hornblende (Altherr \& Siebel, 2002; Henjes-Kunst et al., 1988; Keay et al., 2001; Wijbrans \& McDougall, 1988).

These results are consistent with those obtained for the $\mathrm{MP}-\mathrm{H} T$ retrograde metamorphism (Gautier et al., 1993), and trace elements content, especially $\mathrm{Y}, \mathrm{Nb}, \mathrm{Rb}$, and $\mathrm{Ba}$, fit a gneissic source for this monzogranite (Pe-Piper et al., 1997). All these data indicate a postorogenic intrusion with a dominant crustal contribution emplaced in an extensional context (Pe-Piper et al., 1997). The monzogranite is intersected by a late leucogranite that is a late differentiation of the same hornblende-biotite-bearing magma (Pe-Piper et al., 1997).

These observations support a syn-extensional emplacement of the intrusion associated to the Naxos-Paros Detachment System characterized by three major structures according to Siebenaller (2008): (1) a "décollement" operating at the boundary between the amphibolite facies and greenschist facies metamorphic rocks, (2) a "décollement" operating within the greenschist facies metamorphic rocks, and (3) an upper brittle detachment separating the greenschist facies rocks and the UCU.

\section{Large-Scale Geometry and Internal Architecture of the Intrusion}

\subsection{Finite Strain Markers}

Only few field studies focused on the geometry of the monzogranite intrusion of Naxos (Gautier et al., 1993). To document the overall geometry of the intrusion and then to study the internal distribution of strain, we first complemented the geological map of Naxos (Jansen, 1973; Siebenaller, 2008) and described finite strain markers over the whole intrusion. The resulting new structural map of the intrusion is proposed in Figure 2 . Results from the measurements of finite strain markers are presented in two synthetic maps showing either the foliation or the lineation and associated sense of shear (Figures $2 \mathrm{a}$ and $2 \mathrm{~b}$ ).

Foliation is heterogeneously developed within the Naxos intrusion. The dip of the foliation displays a large range of variation from $0^{\circ}$ to $90^{\circ}$ while most dips are comprised between $\sim 25^{\circ}$ and $50^{\circ}$. Subvertical and steeply dipping foliation planes appear restricted to the center of the intrusion, near Aghios Nikolaos (Figure 2). At 


\section{QAGU Tectonics}
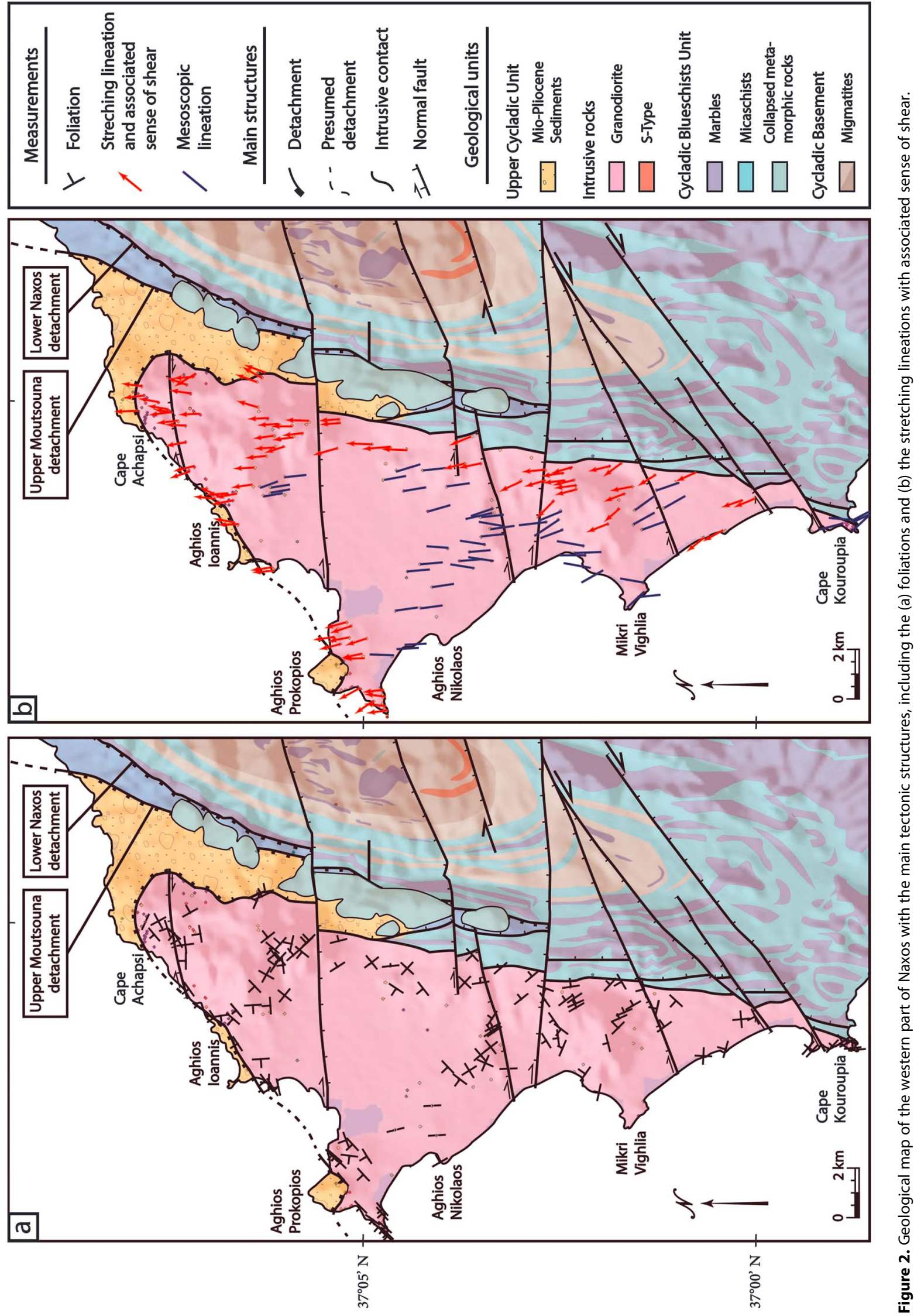
first glance, the foliation planes commonly dip away from the center of the intrusion and the attitude of foliation traces shows a dome-shaped pattern marked by a NNE long axis (Figure 2a). This curved pattern is best expressed in the northern part of the intrusion where the foliation planes rapidly turn from a $\mathrm{N}^{\circ} 0^{\circ}$ preferred orientation along the NW coast to more $\mathrm{N} 90^{\circ}$ to $\mathrm{N} 120^{\circ}$ along the NE contact.

Stretching lineation is a common feature of the intrusion. It is mostly outlined by the elongation of primary minerals (K-feldspar) and by the orientation of phyllosilicate aggregates. Orientation of the stretching lineation shows very little dispersion. Trends are comprised between $\mathrm{N} 010^{\circ}$ and $\mathrm{N} 340^{\circ}$, with an average value close to $\mathrm{N}^{\circ}$ (Figure $2 \mathrm{~b}$ ), while plunges are consistently oriented toward the north. When the sense of shear (top-to-the-north) can be deduced, the stretching lineation is overall plunging to the north, with variations from top to the NNW to top to the NNE (Figure 2b). Rocks in the vicinity of the UCU and locally the Naxos MCC exhibit an intense top-to-the-N shearing deformation (Figure $2 \mathrm{~b}$ ). There, kinematic indicators (asymmetric boudinage, rotations, large-scale sigmoïds, or micafishes into the $X$ - $Z$ plane) are restricted to a dense array of top-to-the- $\mathrm{N}$ shear bands. Conversely, less deformed areas present a less noncoaxial deformation, and numerous outcrops only display a clear N-S stretching or mineral lineation (Figure 2b).

\subsection{Description of the First-Order Geometry}

From south to north, different types of contact of the monzogranitic intrusion with the host rocks can be observed with a high variability in terms of deformation intensity.

At Cape Kouroupia, in the southern part of the intrusion, field observations show a folded intrusive contact between the monzogranite intrusion and enclosing gneisses and marbles (Figures $3 \mathrm{a}$ and $3 \mathrm{~b}$ ). Numerous gneissic septa are present into the intrusive body, and the metamorphic host rocks are injected by an important dike array (Figures $3 \mathrm{c}$ and $3 \mathrm{~d}$ ). A gradual transition from the metamorphic host rocks to the monzogranite is observed with the appearance of granodioritic veins in gneisses, and then gneissic fragments embedded in the monzogranite, ending with the complete disappearance of the metamorphic rocks (Figure 3b). Finally, foliations measured in the monzogranite near the intrusive contact are generally steeply dipping (average value of orientations $\mathrm{N} 147^{\circ}$ with a dip of $60^{\circ}$ to the NE), while they are moderately dipping in the gneiss (orientation mean $\mathrm{N} 154^{\circ}$ and a dip of $40^{\circ}$ to the NE) (Figure 3a). In addition, tension gashes filled with tourmaline are observed in the intrusive veins, mostly oriented NW-SE, and compatible with a dextral component of deformation (Figure 3d). In parallel, numerous elongated mafic enclaves are present, with sharp or diffuse margins, sometimes cut by late leucocratic dikes (aplite). More or less extensive schlierens zones, sometimes folded, are also noticed (Figure 3e), as well as the occurrence of folded injection veins (Figure 3f). Late-magmatic deformation is highlighted by $\mathrm{N}^{\circ} 5^{\circ} \mathrm{E}$ trending fractures filled with tourmaline, in the K-feldspar phenocrysts. Similarly, these K-feldspars can be affected by $\mathrm{N} 40^{\circ} \mathrm{E}$ oriented fractures with quartz filling. Locally, skarns are observed either in marble or along the contact between the monzogranite and the gneisses (Figure $3 \mathrm{~g}$ ). Finally, the marbles are affected by significant fracturing linked to strike-slip faulting (Figure 3a).

In the northern part of the intrusion, Cape Achapsi area is characterized by a well-marked tectonic contact between the monzogranite and Miocene conglomerates (Figure 4). This contact is marked by a clear-cut detachment plane dipping $20^{\circ}$ to the north on top of a massive $50 \mathrm{~m}$ thick cataclasite consisting in a finegrained greenish matrix with clasts smaller than $1 \mathrm{~cm}$ and numerous inframillimetric pyrites, along joints (Figure $4 \mathrm{~b}$ ). The detachment plane is marked by large-scale corrugations oriented $\mathrm{N} 10^{\circ} \mathrm{E}$. Conglomerates in the hanging wall are affected by brittle deformation, marked by fracturing of pebbles indicating a NW-SE extension. Below this major tectonic contact, a strain gradient both in the ductile and brittle regimes is observed in the monzogranite in all the area of Cape Achapsi, not yet described precisely.

\subsection{Mapping the Strain Gradient Within the Intrusion}

In order to map the strain distribution within the Naxos intrusion, a deformation scale was constructed based on macrostructural criteria observed in the field (e.g., Agard et al., 2011), consistent with microstructural observations. This approach is similar, on the principle, to that conducted in recent studies (Charles et al., 2011; Huet et al., 2009; Laurent et al., 2015).

\subsubsection{Scale of Deformation Intensity}

The gradual evolution of deformation intensity from magmatic to subsolidus conditions has been separated in six strain grades based on structural and textural field observations. This scale starts from the magmatic stage with grade 0 and ends in the ductile-then-brittle conditions with grade 5 as follows: 

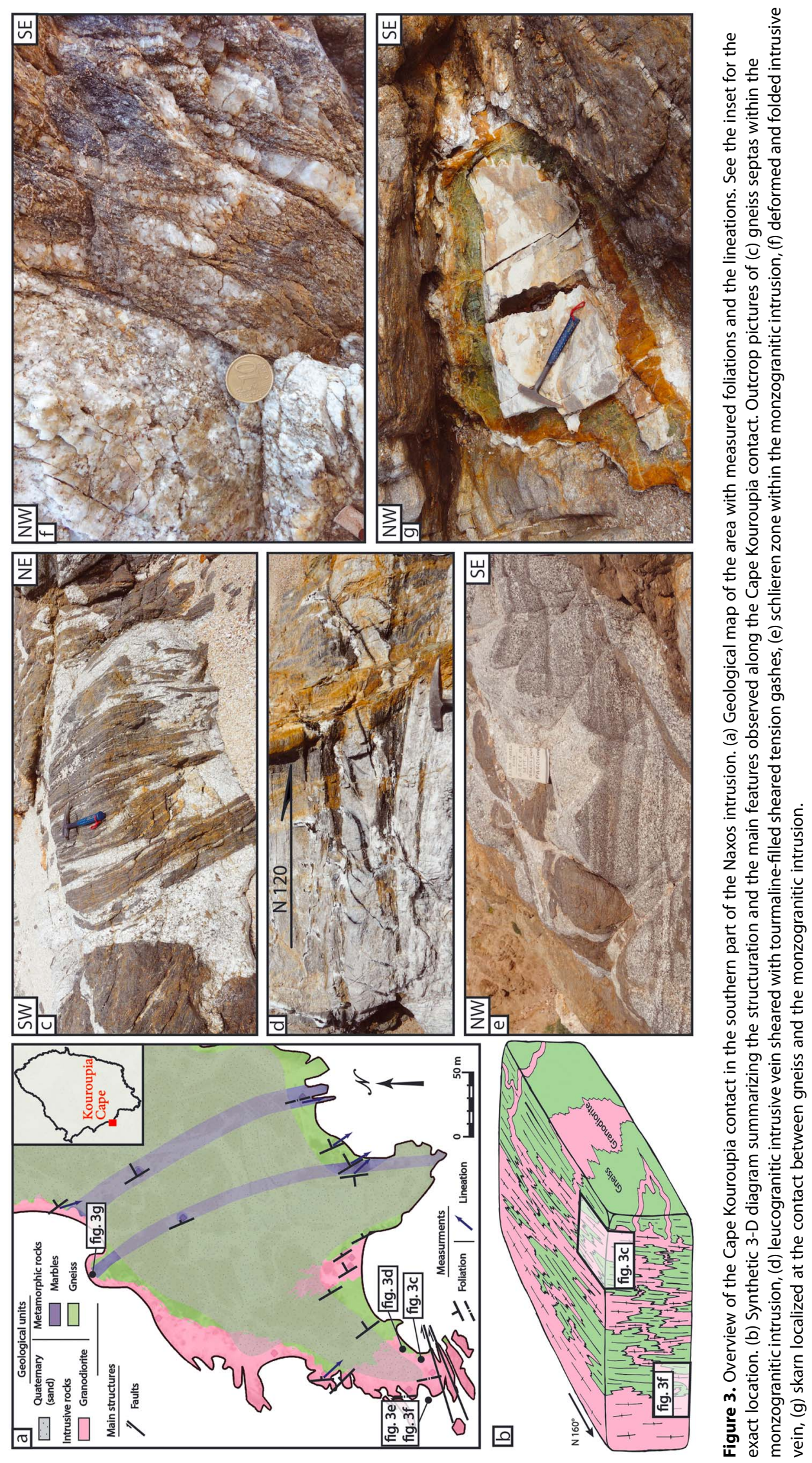


\section{QAGU Tectonics}
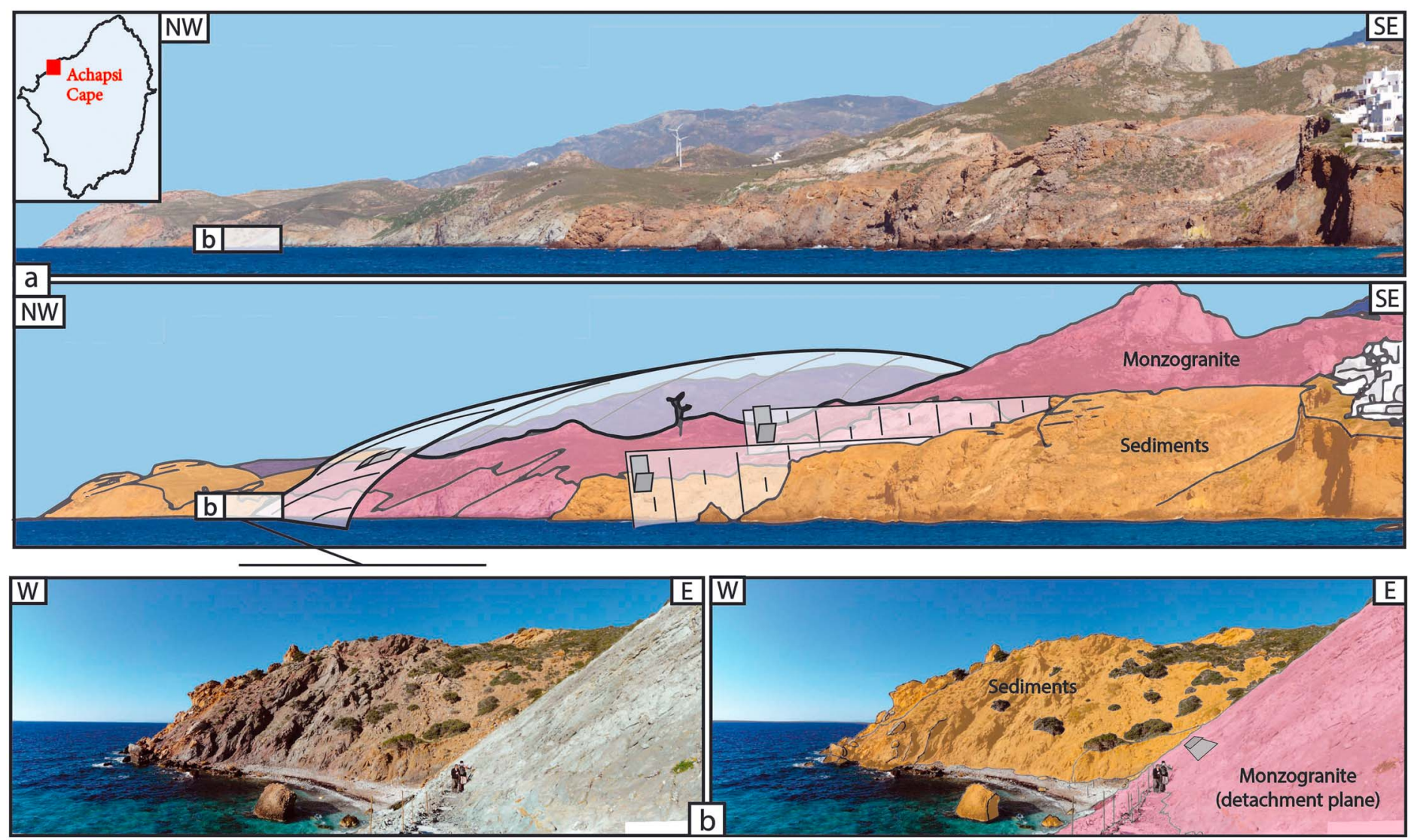

Figure 4. Overview of the Cape Achapsi contact in the northern part of the Naxos intrusion. (a) Panorama view of the Cape Achapsi from the Naxos port. The tectonic contact, with top-to-the-north kinematic, between Miocene sediments and the Naxos monzogranite is segmented by late normal faults. (b) Detailed picture of the detachment plane showing the Miocene sediments overlying the monzogranite. Corrugations oriented N10 $0^{\circ}$ are accompanied by a top-to-the-north kinematics.

Grade 0 corresponds to an isotropic magmatic fabric (Figure 5a). The term "magmatic fabric" is used in the mechanical sense, when there is no direct interaction (contact) in the magma between crystals (Vernon, 2000). A magmatic preferred orientation, mainly corresponding to the alignment of K-feldspar phenocrystals, starts to develop with a low shape fabric intensity. In the field, the monzogranite shows neither clear planar nor linear shape fabrics, and minerals are not deformed. This grade generally preserves mafic enclaves, even schlierens or phenocrysts of feldspar.

Grade 1 corresponds to a clear anisotropic magmatic fabric (Figure 5b). Minerals are not deformed but an incipient foliation and/or lineation can be observed, especially with the preferred alignment of biotite and amphibole. Phenocrysts of feldspar are still visible and mafic enclaves display a profiled and oriented shape.

Grade 2 can no longer be considered as a pure magmatic fabric (Figure 5c). Feldspar megacrysts start to be deformed, suggesting contact interactions between crystals in a solid network within the magma. Some feldspar phenocrysts are not deformed while others are stretched, boudinaged, and sheared. Additionally, mafic enclaves are now clearly deformed with slender shapes and smaller dimensions. Elongated clusters of biotite mark the stretching lineation.

Grade 3 is marked by the appearance of a weak tectonic foliation, a clear stretching lineation, a few penetrative shear bands that affect large volume of rocks, grain-size reduction, and clear quartz ribbons (Figure $5 \mathrm{~d}$ ). This shape fabric can be qualified as protomylonitic.

Grade 4 is characterized by a strong foliation and lineation with increasing number and thickness of shear bands associated with stretched biotite and quartz ribbons (Figure 5e). This shape fabric can be qualified as mylonitic.

Grade 5 shows both a thickening and an interconnection of the mylonite shear bands that can evolve in dark ultramylonite bands (Figure 5f). Ultramylonite bands are defined by an intense grain size reduction 


\section{QAGU Tectonics}
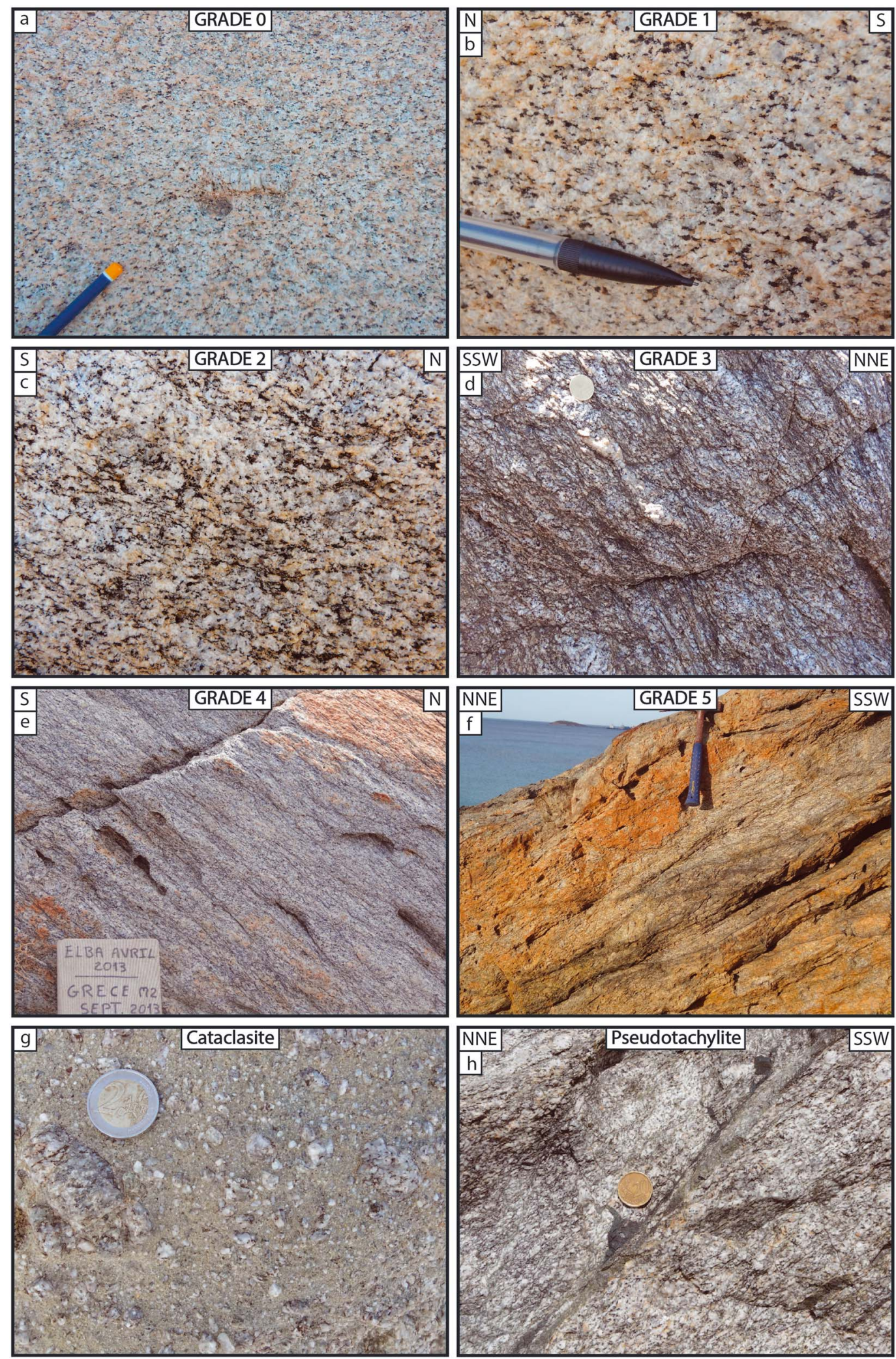

Figure 5. Presentation of the deformation intensity scale with field pictures. (a) Grade 0, isotropic magmatic fabric. (b) Grade 1, anisotropic magmatic fabric. (c) Grade 2, rocks showing first evidences of ductile deformation (feldspar megacrysts are stretched, buodinaged and/or sheared mafic enclaves are deformed, and elongated clusters of biotite mark the stretching lineation). (d) Grade 3, appearance of the first shear bands. (e) Grade 4, first utramylonitic bands. (f) Grade 5, intensification and development of ultramylonitic bands. (g) Cataclasites. (h) Pseudotachylite veins. 
resulting in phase mixing and the full loss of the magmatic character of the rocks. Mainly no visible grains are observed or only few small feldspar remnant clasts. Individual thickness of these bands does not straightforwardly evolve while their spacing drastically decreases.

In addition to this scale of ductile deformation intensity, brittle/cataclastic features were recognized and mapped separately. Two different brittle features were described.

1. Cataclasites that usually overprint the upper $\sim 50$ to $150 \mathrm{~m}$ of grade 5 mylonites. Cataclasites are strongly chloritized and are characterized by various grain sizes (Figure $5 \mathrm{~g}$ ). Intensity of the former ductile deformation is often difficult to recognize.

2. Pseudotachylite veins that are mainly localized in grade 5 and more precisely inside ultramylonitic bands. Layers are $1 \mathrm{~mm}$ to $5 \mathrm{~mm}$ thick, often anostomosed and are accompanied by stretching-perpendicular injection veins (Figure $5 \mathrm{~h}$ ).

\subsubsection{Strain Distribution at the Scale of the Naxos Intrusion}

This scale of finite deformation was used to map the strain distribution within the Naxos intrusion. Twohundred forty-five outcrops were visited (colored points in Figure 6). Results show a gradual increase in strain intensity from the internal parts of the intrusion to the contact with the surrounding wall rocks (Figure 6). The least deformed rocks are found from the southwest coast between the Aghios Nikolaos and Mikri Vighlia villages (Figure 6). Strain grades arranged as concentric zones draw quite continuous strain gradients approaching the contact zone with the upper unit where strongly deformed rocks occur. Internal architecture of this strain gradient that is spectacularly exposed along the coast at the Aghios Prokopios can be studied as a representative example (see location in Figure 6).

There, deformation intensity increases significantly from south to north over an approximately $1 \mathrm{~km}$ thick strain gradient, from the first evidence of strain localization (grade 2) to ultramylonitic facies (grade 5) (Figures $7 \mathrm{a}$ and $7 \mathrm{~b}$ ). Three-dimensional sketches illustrate the different key outcrops as well as the evolution of deformation intensity of the peninsula (Figures 7c to 7f). To the south, the Aghios Nikolaos area is only characterized by a weak magmatic fabric or even isotropic magmatic facies (Figure 6).

First evidence of strain localization (grade 2) occur $1000 \mathrm{~m}$ below the contact. Deformation incipiently localizes around K-feldspar phenocrysts with the alignment of biotite flakes. Mineral orientation is then increasingly pronounced, particularly for biotite grains (Figure 7c). Then, K-feldspar phenocrysts are boudinaged, associated with the appearance of sigmoidal foliation, shear bands, and mica fish. Foliation shows a regular dip of $35^{\circ}$ to the NW, with a northwest trending stretching lineation (Figure 7a). The associated sense of shear is also consistent, always top-to-the-NNW. This is accompanied by a significant reduction of grain size (quartz and feldspars) and the disappearance of feldspar phenocrysts (Figure 7d). From $600 \mathrm{~m}$ below the contact, the number and thickness of shear bands gradually increase with locally small ultramylonite bands. K-feldspars are often affected by antithetic shears. It is also worth to note the pronounced shape fabric of quartz grains in the sigmoidal foliation between shear bands (Figure 7e). From 150-250 m below the contact, ultramylonite bands appear, displaying an overall strike $\mathrm{N} 50^{\circ}$ with a dip of $\mathrm{N} 50^{\circ}$ to the northwest, while shear planes show strikes around $\mathrm{N}^{\circ} 2^{\circ}$ and a dip of $38^{\circ}$ to the northwest. The sense of shear remains top to the NNW. Toward the contact, ultramylonite bands anastomose. However, the ductile fabric is locally strongly overprinted by brittle features such as a 60-100 m thick cataclasite body and localized pseudotachylite veins. Pseudotachylite veins that occur as a locally dense array are either parallel to the ultramylonitic bands or perpendicular to them, filling extensional veins perpendicular to the stretching direction (Figure 7f). Cataclasites occur as a massive and chloritized cataclastic body characterized by a heterogeneous grain size with elements reaching centimeter scale wrapped into a fine-grained matrix. The upper contact of the intrusion is characterized by a thick fault gouge that marks the contact with diabase belonging to the UCU, itself unconformably overlaid by Miocene sandstones.

\section{Microscopic Observations}

Grades 0 and 1, representative of an isotropic and anisotropic magmatic fabric, are characterized by very few deformed minerals and also by monzonitic textures defined by the growth of large euhedral Kfeldspars including smaller ones (Figure 8a). In addition, observations at microscopic scale show fractures mainly affecting K-feldspars (Figure 8b). Moreover, it is interesting to note that these microfractures tend to disappear gradually as the ductile deformation takes place and becomes more intense. 


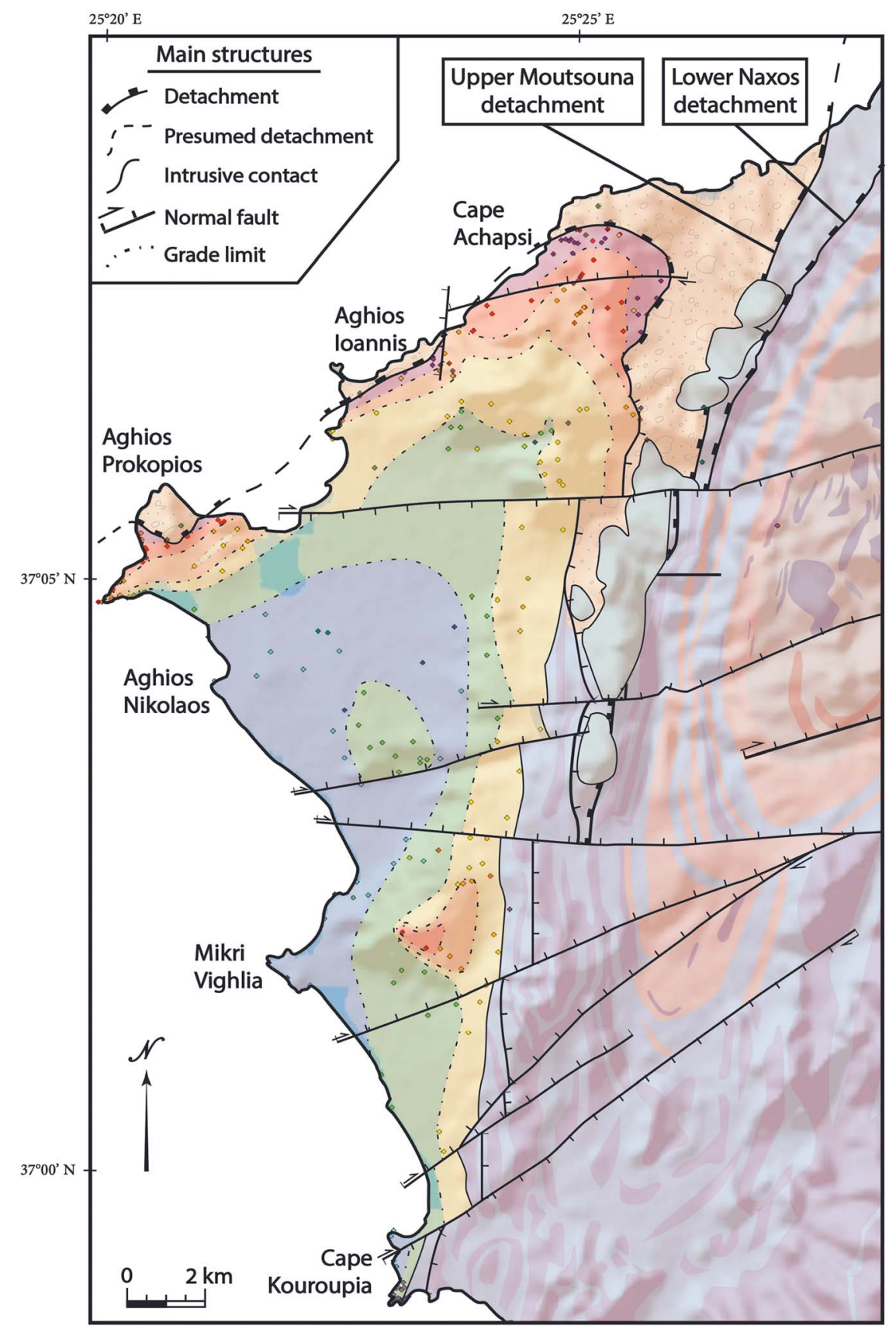

Figure 6. Characterization of the strain gradient within the Naxos intrusion. Qualitative map of deformation showing the heterogeneous distribution and the evolution of both magmatic and ductile deformation in the intrusion. Dotted lines represent the progressive transition between grades and not a fixed limit.

Grade 2 is characterized by an incipient preferential orientation of minerals, especially quartz with a grain size reduction resulting from dynamic recrystallization. Biotites present the first traces of strain, marking planar or linear alignment and wrap around K-feldspars (Figure 8c).

Grade 3 is marked by the appearance and development of shear bands, with a clear alignment of biotite and the appearance of mica fish. However, only slightly deformed biotite clusters are still widely observed. In addition, the boudinage of K-feldspars and hornblendes is now clearly visible and they are affected by the localization of shear bands (Figure $8 \mathrm{~d}$ ).

Grade 4 is characterized by an intensification of finite deformation, especially in K-feldspars that underwent a partial or even a total recrystallization. Boudinage is also more intense, as well as shearing. It is interesting to 


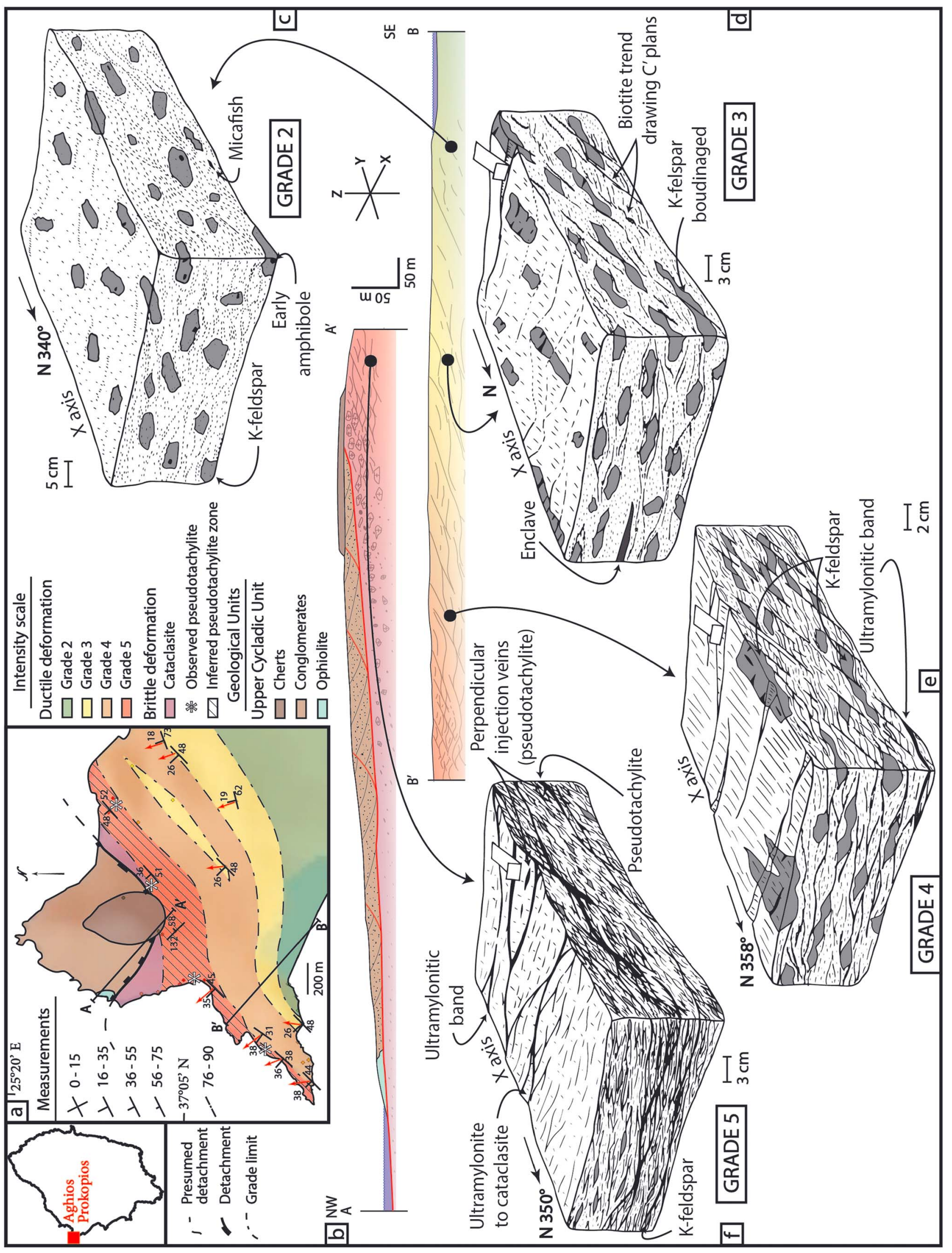

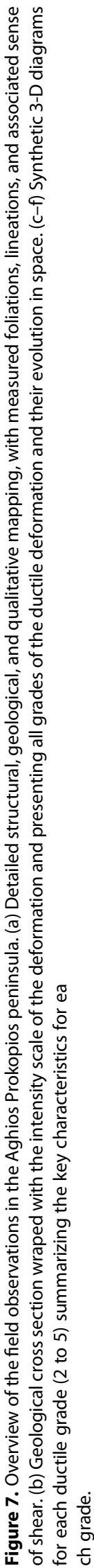



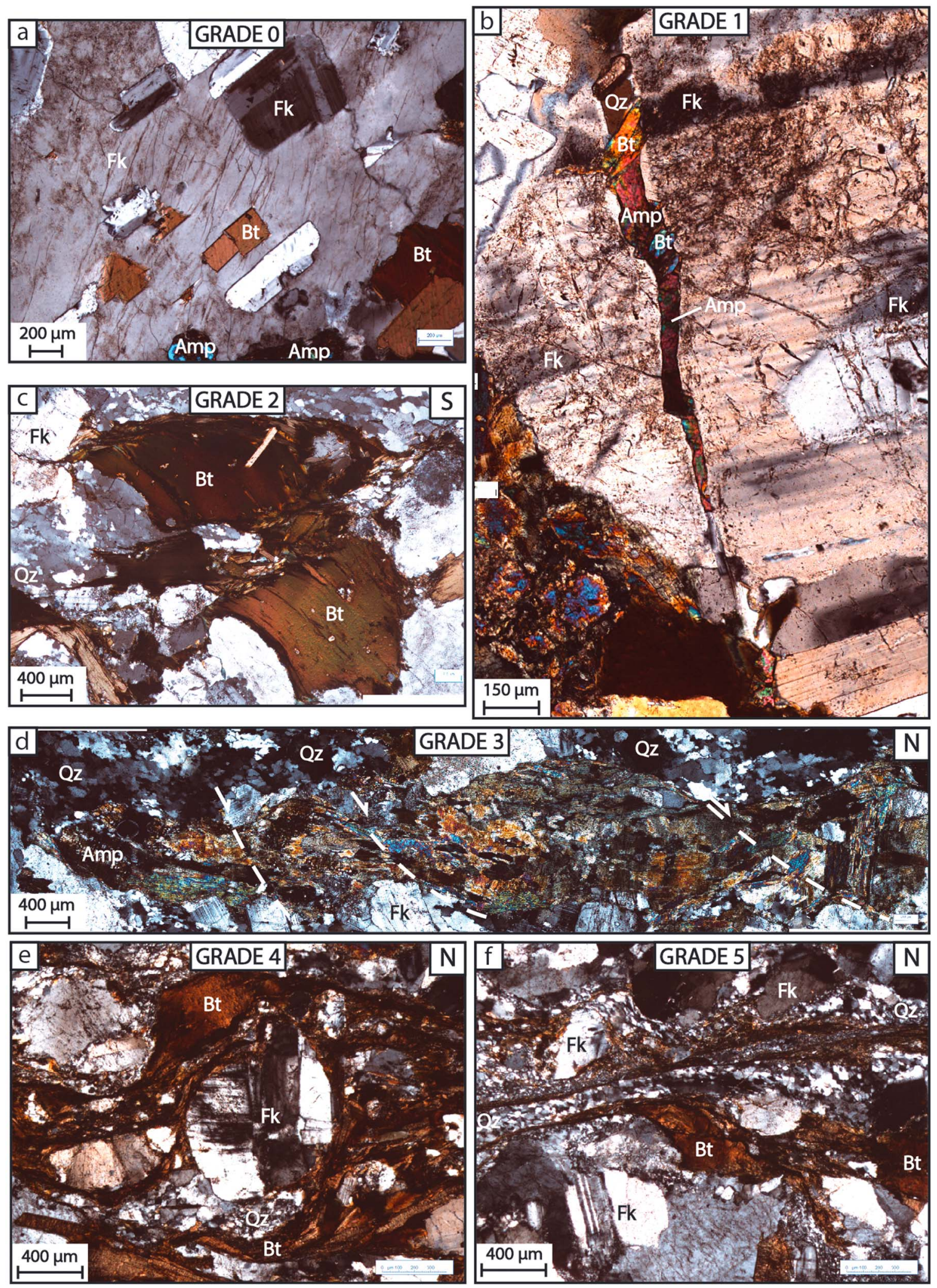

Figure 8. Microscopic observations for each grade of deformation in the XZ plane. Amp, Amphibole; Bt, Biotite; Fk, K-feldspar; and Qz, Quartz. (a) Grade 0, monzonitic texture. (b) Grade 1, syn-magmatic fracture inside a feldspar crystal with a QZ-Bt-Amp filling. (c) Grade 2, first step of biotite deformation. (d) Grade 3, boudinaged and sheared amphibole. (e) Grade 4, first anastomosed microshear bands and antithetic shearing. (f) Grade 5, intense deformation with reoriented and very fine-grained quartz stretched biotites and anastomosed shear bands. 
note that the shear bands affecting feldspars are antithetic, as observed in the field. In the most deformed bands wrapping around the K-feldspar boundins, quartz shows a significant grain size reduction (Figure 8e).

Grade 5 is characterized by a strong increase of K-feldspar boudinage (Figure 8f). In addition, the texture of quartz aggregates shows two successive stages of strain accommodation. The first stage shows grain size reduction associated with a shape-preferred orientation of grains parallel to newly formed quartz ribbon planes. The second stage, locally overprinting the primary texture, is characterized by an additional strong grain size reduction of quartz located in shear bands. The transition between the two quartz textures is clearly visible in shear band boundaries (Figure 8f). Other shear bands initiate along biotite grains that show mica fish morphology. Lengthwise propagation of these bands and their connection with shear bands mainly composed of small new quartz aggregates allow the development of a connected anastomosed network (Figure 8f). Ultimately, an ultramylonitic texture, possibly with some cataclastic flow, is locally evidenced in some shear bands thanks to the presence of K-feldspar angular clasts included in a very fine matrix whose composition remains undeterminable at the scale of observation.

\section{Strain Quantification}

In order to put quantitative constraints on the qualitative distribution of strain deduced from the field approach, a quantitative study of the intensity of the shape fabric is performed, by determining the shapepreferred orientation (SPO) of magmatic minerals. The SPO of minerals can be induced by syn-magmatic and/or subsequent later tectonic deformation. Syn-magmatic deformation is linked with magma dynamics during emplacement of the intrusion and has mainly an impact on the orientation of crystals. Conversely, tectonic deformation appears at any deformation stage and has consequences on both the SPO and the mineral deformation. Determining these parameters allows evaluating and precisely quantifying the deformation history and its intensity.

For each grade of the deformation scale obtained, we thus collect oriented samples from the same cross section (see location in Figure 6), from the south (Aghios Nikolaos) to the north (Aghios Prokopios). We then perform strain quantification by analyzing pictures of the three orthogonal planes: (1) the $X Z$ plane, perpendicular to foliation plane and parallel to lineation, (2) the $Y Z$ plane, perpendicular to lineation, and (3) the $X Y$ plane, parallel to foliation pla2ne.

Several methods were used: (i) X-ray computed tomography was helpful to image cores and produces 3-D views and orthogonal planes, then (ii) analyses of these orthogonal pictures were performed with softwares SPO2003 and Intercept 2003, and finally, (iii) we completed this analysis by an EBSD study.

\subsection{Imaging and Analytical Methods}

\subsubsection{X-Ray Tomography}

$\mathrm{X}$-ray computed tomography is a nondestructive technique that allows the discrimination in a solid volume, mineral on the basis of their bulk densities (Baker et al., 2012; Gualda \& Rivers, 2006; Ketcham, 2005; Ketcham \& Carlson, 2001; Mees et al., 2003). Data were obtained following three steps. 1 . Acquisition of many views by turning the sample from $0^{\circ}$ to $360^{\circ}$, the distance between the X-ray source and the sample determines the final resolution.

2. Reconstruction that consists in determining the attenuation coefficients for each line of pixels in each view using Beer's law (Baker et al., 2012; Ketcham \& Carlson, 2001). This stage also includes artifact correction that comprise beam hardening, ring artifacts, and misalignments (Ketcham \& Carlson, 2001).

3. The stack of slices consists in assembling all 2-D sections of the sample to form the 3-D image of the cores. Data are acquired with a Phoenix Nanotom system with a resolution smaller than $5 \mu \mathrm{m}$ per unit of volume (voxels), while the segmentation of mineral phases was realized by using ImageJ and VG-Studio Max softwares.

\subsubsection{Estimation of the Shape Preferred Orientation}

A $2.5 \mathrm{~cm}$ diameter core from each strain grade was analyzed by $X$-ray tomography. Cores were virtually cut according to $X Z, Y Z$, and $X Y$ planes. Due to the poor differentiation between $\mathrm{K}$-feldspars and quartz on pictures, and a good discrimination between biotite/amphibole and feldspar/quartz groups, we choose a simple segmentation of dark minerals/clear minerals. Images treatment and phase segmentation were done by using both Photoshop and GIMP2 softwares. The filtering and segmentation protocol being identical for all samples, only the grey level values chosen during the final segmentation procedure were different, 
depending to the grey level histogram specific to each picture. More than 30 pictures (2-D images) were extracted for each plane of each sample, giving a total of 570 pictures treated and then analyzed.

First, the SPO analysis of the dark phase composed of biotite and amphibole grains was performed with two different softwares: SPO2003 and Intercepts2003 (Launeau et al., 2010; Launeau \& Robin, 1996; Launeau \& Robin, 2005). SPO2003 software allows determining the eccentricity $R$ and the long axis orientation $\alpha$ of the inertia tensor calculated for each element of the black phase. An element corresponds generally to an individual mineral grain but may also correspond to an aggregate of mineral grains. The average shape fabric of the black phase corresponds to the tensorial mean of the tensors calculated for each element. This method is used when each element is isolated and allows the statistical analysis of the SPO of the whole population. When clusters of elements cannot be separated, Intercepts2003 software was used. The principle of this software is based on the intercepts method, which analyzes the boundaries of the black phase over the entire image as a population of lines. The method involves a Fourier series decomposition of the polar plot of intercepts and yields a rose of directions (Launeau \& Robin, 1996; Saltikov, 1958). As for the inertia tensor method, an eccentricity $R$ and a long axis orientation $\alpha$ can then be calculated for the whole population.

Second, the 3-D fabric ellipsoid was calculated by using the 2-D analyses performed on the three orthogonal faces of our samples (Launeau et al., 2010). The reconstruction of this ellipsoid allowed calculating the degree of anisotropy $\left(P^{\prime}\right)$ and the shape parameter $(T)$ of the biotite/amphibole fabric for each association of images (eight associations for each grade) (Jelinek, 1981; Launeau \& Robin, 2005). $P^{\prime}$ refers to the eccentricity of the 3-D fabric ellipsoid and can be correlated with the intensity of the biotite/amphibole preferred orientation. $T$ refers to the symmetry of the 3-D fabric ellipsoid. Three cases were considered: (1) if the value of $T$ is lower than -0.2 , lineation is dominant and the form of the ellipsoid is oblate, (2) if the value of $T$ is comprised between -0.2 and 0.2 , the lineation and foliation intensities are equivalent or similar, and (3) if the value of $T$ is superior to 0.2 , the foliation is dominant and the form of the ellipsoid is prolate (see equations in Borradaile \& Werner, 1994).

\subsubsection{Quartz Lattice Preferred Orientation}

During ductile flow, rock-forming minerals are subjected to plastic deformation that may give rise to some lattice preferred orientation (LPO) depending on the dominant deformation mechanism, like grain sizeinsentive dislocation creep or grain size-sensitive creep (Kilian et al., 2011; Otani \& Wallis, 2006). For crustal rocks, the pattern of quartz LPO also provides crucial information on temperature conditions, finite strain, and kinematics during deformation (Heilbronner \& Tullis, 2006; Stipp et al., 2002). To better characterize the deformation conditions involved during strain localization within the Naxos monzogranite, we thus documented the quartz LPO through electron backscatter diffraction (EBSD) analyses. EBSD data were collected using a scanning electron microscope coupled with an EDAX Pegasus system at ISTO/BRGM (Orléans, France). Analytical conditions involved a working distance of $15 \mathrm{~mm}$, an acceleration voltage of $20 \mathrm{kV}$, and a probe current of $\sim 6 \mathrm{nA}$ on polished thin sections (diamond paste of $0.25 \mu \mathrm{m}$ followed by colloidal silica). In order to avoid indexing errors, equal-area lower hemisphere pole figures have been constructed using one measurement per grain collected manually through a whole thin section. For EBSD maps, we considered the mean orientations of each grain that compose the whole map or a selected area. The isocontours and grey shadings on pole figures were plotted using the UNICEF careware software package (Mainprice; www. gm.univ-montp2.fr/PERSO/mainprice/W_data/CareWare_Unicef_Programs). To plot EBSD maps and to calculate the texture $(J)$ and misorientation $(M)$ indices, which both give the degree of mineral alignment between $J=1 / M=0$ for a random orientation and $J=\infty / M=1$ for a crystal-like alignment, we used the OIM software (EDAX) and the open-source matlab-based MTEX toolbox (Bachmann et al., 2010; Mainprice et al., 2015). Each map has been cleaned considering a minimum of five neighbor-based pixels on several raws. Using MTEX, we also merged dauphine-type twin boundaries with parent grains and we chose to define the size of recrystallized grains by selecting grains with a maximum intragranular misorientation angle of $10^{\circ}$ (the misorientation is calculated for each grain with respect to their respective mean orientation). Both poles, figures and $J_{\text {index }}$ were calculated using a Gaussian half-width angle of $10^{\circ}$.

\subsection{Results}

\subsubsection{X-Ray Tomography}

X-ray tomography imaging allows us visualizing the sample in 3-D. It is also possible to make segregation of the phases based on their response to radiation and thus access to a 3-D view of mineral shape fabric inside the core. We can thus visualize in 3-D the main stages of our deformation intensity scale by evidencing an 
evolution of the internal structure of the sample according to the deformation intensity that is very similar to the previous macroscopic and microscopic descriptions (Figure 9). Indeed, grade 0 is characterized by an isotropic magmatic fabric (Figure 9a) that evolves toward a localization of deformation with a preferred orientation of the dark minerals (biotite and amphibole; Figure 9b), finally reaching grade 5 where deformation is marked by pervasive structures and the development of ultramylonite shear bands (Figure 9c).

\subsubsection{Shape Preferred Orientation}

The $P^{\prime}$ and $T$ fabric parameters for the six grades are shown in Figure 10 . The $P^{\prime}=f(T)$ diagram clearly shows an evolution of the shape parameter $(T)$ and the degree of anisotropy $\left(P^{\prime}\right)$. Results highlight a good correlation between $P^{\prime}$ and the qualitative scale based on field observations. Indeed, the first grade (grade 0 ) is characterized by the lowest anisotropy degree, with $P^{\prime} \sim 1.11$, while grade 5 presents the highest values with $P^{\prime}$ $\sim 1.58$. In the same way, an evolution of $T$ (shape parameter) is observed with the degree of anisotropy $P^{\prime}$. Thus, the ellipsoid in the lowest grade is characterized by a prolate shape and evolves progressively toward a nearly perfect oblate shape with respect to the increasing anisotropy degree.

\subsubsection{Quartz Lattice Preferred Orientation}

In Figure 11, we show the quartz LPO for each grade of the monzogranite intrusion. LPOs are shown with respect to the foliation and lineation, such as observed in the field or defined by tomographic images (for grades 0 and 1, Figure 11a). From grades 0 to 5, that is, with increasing strain and decreasing grain size, we document a similar pattern of quartz LPO, which involves the [c] ([0001]) axes normal to the lineation within the foliation plane. Accordingly, the $\langle a\rangle(\langle 11-20\rangle)$ axes distribute within a solid angle of $90^{\circ}$ around the $[c]$ axis maximum with six maxima located at $60^{\circ}$ from each other, such as expected for the crystal system of quartz (trigonal 32). This type of LPO is typical of prism <a> slip LPO (Muto et al., 2011; Stipp et al., 2002), but the $[c]$ axis also tends to form a girdle around the $X$ axis in high-strain grades (3-5), suggesting a weak activation of other slip systems. Furthermore, the strength of quartz LPO first increases from grade 0 $(J=4.35 ; M=0.07)$ to grade $2(J=7.55 ; M=0.36)$ and then decreases up to grade $4(J=3.36 ; M=0.19)$, before slightly increasing again to grade $5(J=3.57 ; M=0.24)$ (Figure $11 \mathrm{~b})$. The strength drop is correlated with weakening of the $[c]$ axis around $Y$ and smearing out of the $\langle a>$ axes maxima in the $X-Z$ plane. These features are further supported by the distribution of uncorrelated misorientation angles (Figure 11c), which starts from a close to random distribution (dotted line in Figure 11b) in grade 0, progressively shifts toward low values up to grade 2, and then shift back to higher values for grades 4 and 5 . At a first order, we therefore document a moderate mineral alignment strength that first strengthens and then weakens with increasing strain and decreasing grain size.

To better document the quartz-preferred orientation of high-strain samples, we perform high-resolution $(<1 \mu \mathrm{m}$ step size) EBSD maps within quartz-rich shear bands (Figure 12). We chose to focus on grade 4 where shear bands are easy to isolate from each other. These maps document monomineralic quartz aggregates with a mean grain size of $\sim 30 \mu \mathrm{m}$ and a unimodal lognormal distribution, suggesting a high degree of dynamic recrystallization (Figures $12 \mathrm{a}$ and 12b). No change occurs in the LPO pattern (prism $<a>$ slip LPO), and we document a moderate mineral alignment strength with $J=3.86$ and $M=0.29$, such as revealed by the $c[0001]$ axis pole figure (Figure 12d) and inverse pole figure combined with the EBSD map (Figure 12a). Despite large finite strain, the mineral alignment strength in shear bands thus remains very similar to the overall shape fabric of grade 4 (Figure 11). However, while some areas show quartz grains that have a strong alignment strength-the stronger one documented so far $(J=7.47$; $M=0.42$; Figure $12 \mathrm{E}_{1}$ )-some others show a weak alignment, weaker than ever documented across the whole shear zone $\left(J=2.7 ; M=0.18\right.$; Figure $\left.12 \mathrm{E}_{2}\right)$. The mean grain size slightly decreases between the high-strength area $(31.5 \mu \mathrm{m})$ and low-strength area $(29.6 \mu \mathrm{m})$. Accordingly, the distribution of uncorrelated misorientation angles significantly shifts toward low values for the high-strength area and tends to the uniform distribution for the low-strength area (Figures 12 E1 and E2). The mineral alignement strength therefore does not distribute homogeneously across the high-strain shear bands.

In addition, we used EBSD maps to document the distribution of subgrain boundaries (i.e., correlated misorientation angles between 2 and $10^{\circ}$ ) in quartz-rich shear bands and tails of recrystallized grains (Figure 13). In shear bands, we highlight numerous four-grain junctions and a significant amount of subgrain boundaries with rotation angles that distribute around the $c$ [0001] axis (Figure 13a), which is consistent with dominant tilt boundaries induced by dislocation glide on the $\{m\}<a>$ slip system, in aggreement with prism $<a>$ slip LPO (Lloyd, 2004) (Figures 13a and 13b). We also identify a significant amount of recrystallized grains 

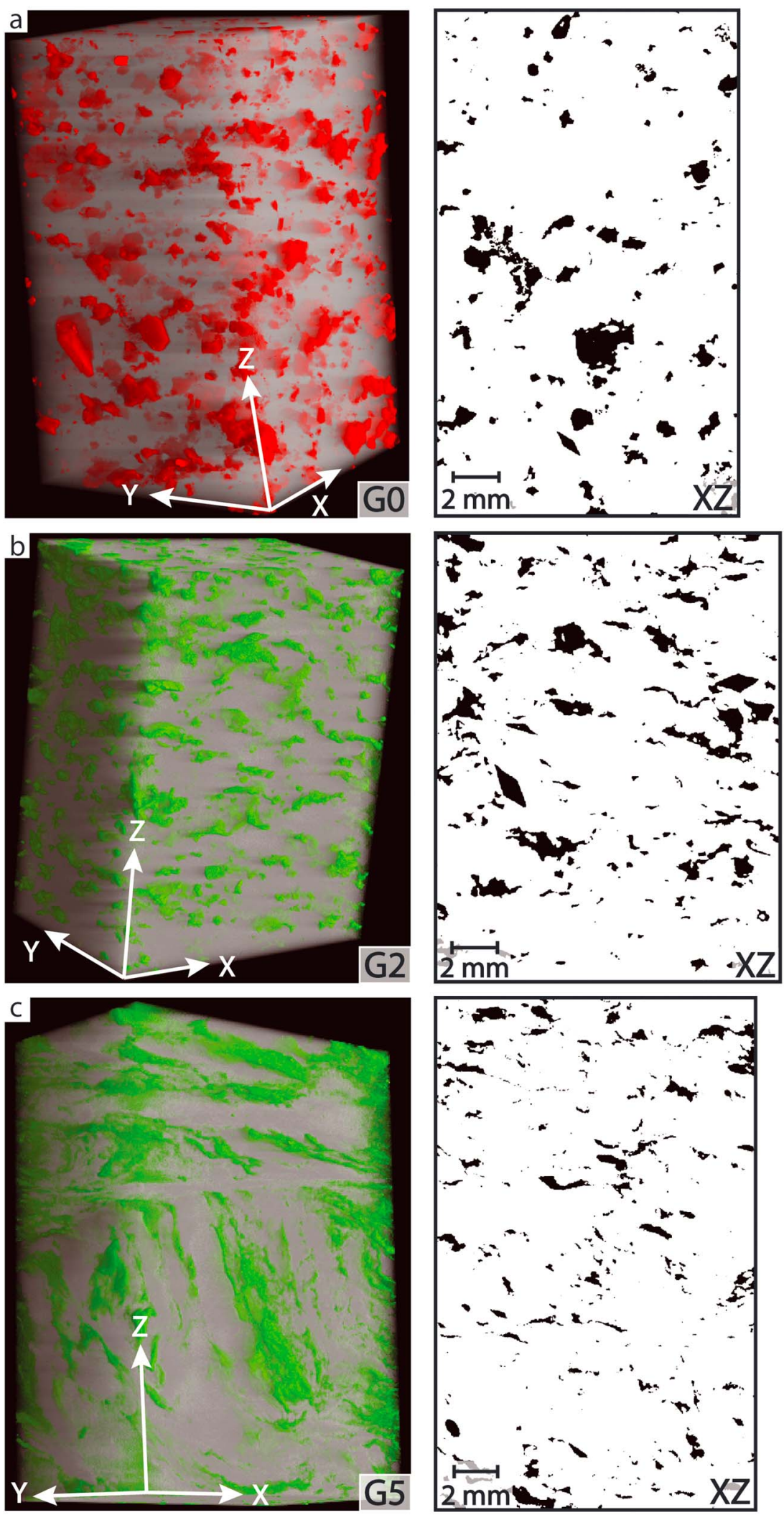

Figure 9. Three-dimensional views of imaged cores by X-ray tomography method and the associated 2-D pictures (XZ plane) extracted from the 3-D views. (a) Grade 0. (b) Grade 2. (c) Grade 5. 


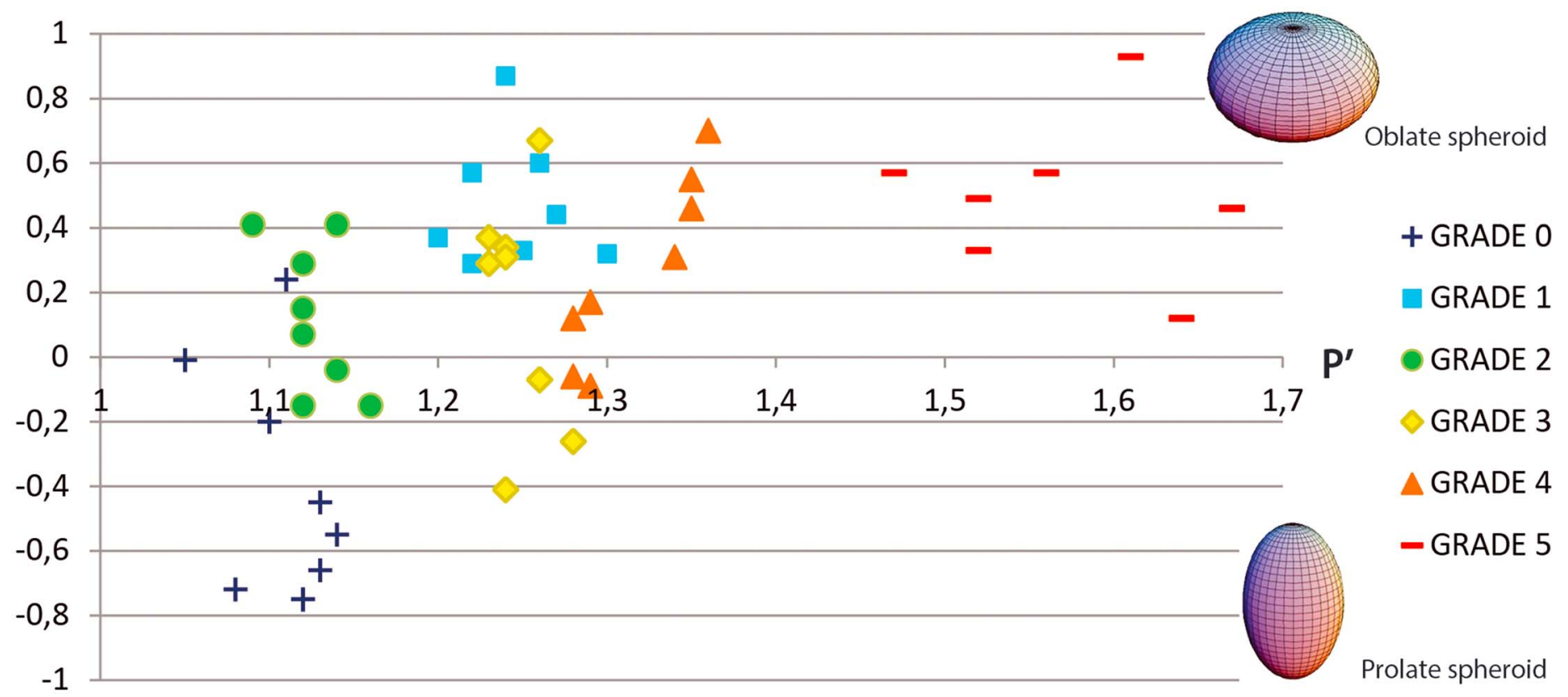

Figure 10. Shape parameter $(T)$ versus anisotropic degree $\left(P^{\prime}\right)$ diagram characterizing the shape preferred orientation (SPO) of magmatic minerals (biotites and amphiboles) with increasing strain, that is, from grade 0 to $5 . P^{\prime}$ and $T$ describe and quantify a 3-D ellipsoid calculated by using the 2-D images from the three orthogonal faces of our samples. Each point represents the obtained result from the 2-D image association.

between 10 and $100 \mu \mathrm{m}$ with a mean grain size and mode (following a lognormal distribution) of $26.2 \mu \mathrm{m}$ and $\sim 19 \mu \mathrm{m}$, respectively (Figure 13c). In contrast, we document large grains with lobate boundaries and a few subgrain boundaries in recrystallized tails of quartz porphyroclasts, most of these latter standing by the fine-grained shear band (Figure 13d). Yet, we document a clear c[0001] axis maxima that stands parallel to $Y$, such as observed in the whole intrusion (Figure 13e). Quartz porphyroclasts also contain plenty of healed cracks with fluid inclusions (Figure 13d).

\section{Discussion}

\subsection{Evolution of Shape Fabrics Along Strain Gradient}

A schematic evolution of the $P^{\prime}-T$ parameters characterizing the shape fabric ellipsoid with increasing deformation is represented in Figure 14 by using the means and associated standard deviation of each grade. Based on our field observations and the shape fabric analyses, we propose to divide the evolution of the shape fabric in four successive stages (colored arrows, Figure 14).

Stage 1 corresponds to the progressive evolution from a prolate magmatic fabric with low eccentricity $\left(P^{\prime} \sim 1.11\right)$ toward a clear oblate fabric with a moderate eccentricity in grade 1 . The prolate fabric in grade 0 is due to the shape-preferred orientation of amphiboles, while biotite flakes do not show any clear preferred orientation (Figure 8a). Grade 1 already shows a clear evolution of the degree of anisotropy, from $11 \%$ to about $25 \%$, together with a flattening of the ellipsoid, which becomes strongly oblate $(T=0.47)$. This evolution is correlated with the marked organization of biotites developing a flatten shape preferred orientation. This transition from a prolate to an oblate magmatic fabric can be viewed as an evolution from a purely constrictional magmatic flow to a syn-magmatic deformation (weakly oblate fabric), tectonically driven by the north directed regional extension.

Stage 2 corresponds to an evolution from an oblate to a plano-linear shape fabric associated with a decrease in eccentricity between the grades 1 and 2 . Grade 2 shows scattered $T$ values $(-0.15$ to 0.41$)$ showing the progressive strain localization by the localized reorientation of biotite grains (Figure 8c). This evolution in shape fabric properties of the ferromagnesian phases exemplifies a local superimposition of the 

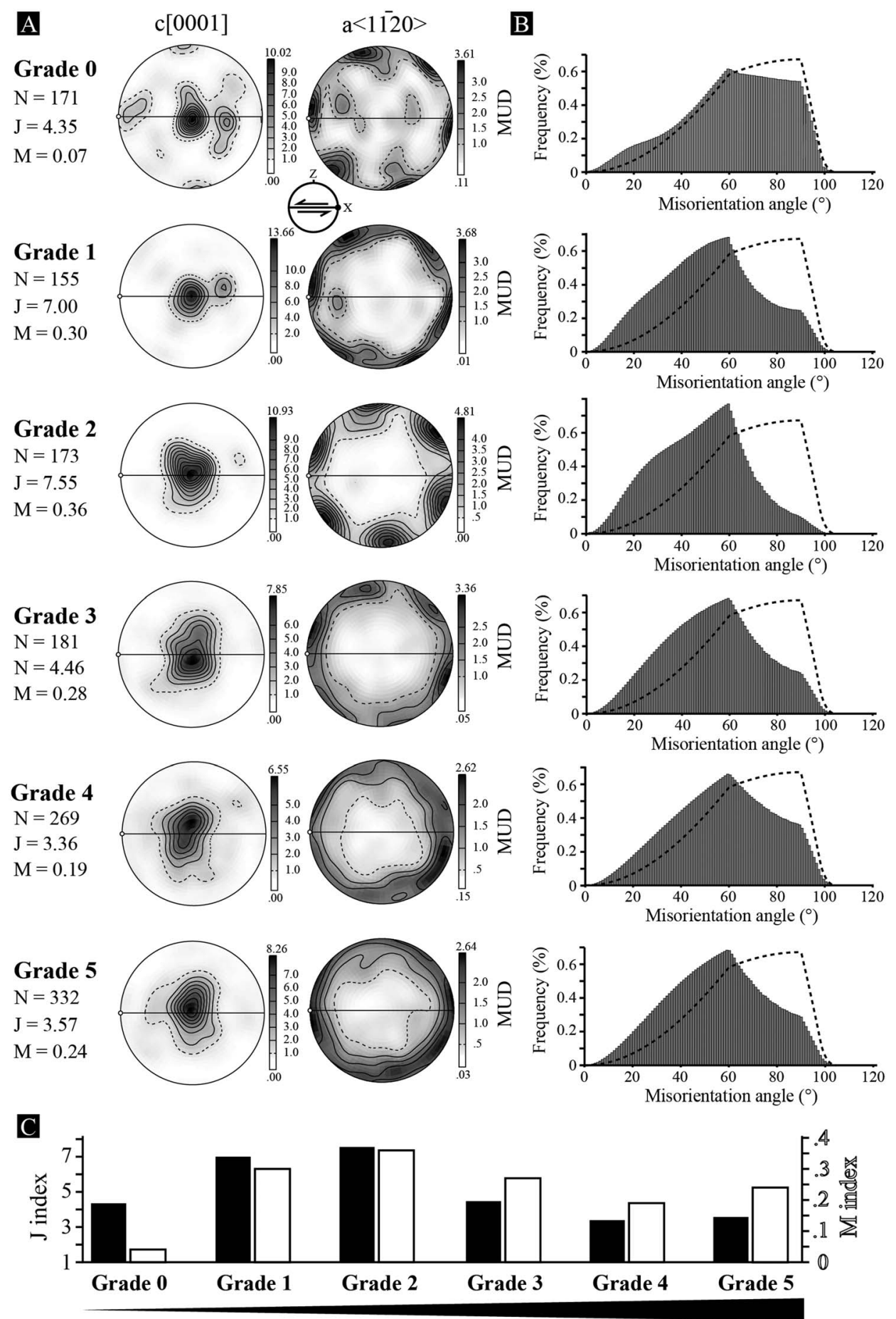

Finite strain

Figure 11. Quartz lattice preferred orientation (LPO) across the Naxos intrusion. (a) Equal-area lower hemisphere pole figures of the $c[0001]$ and $a<11-20>$ axes for trigonal quartz with increasing strain, that is, from grades 0 to 5 . Pole figures are shown with respect to the foliation (horizontal line) and lineation (white dot) in the $X Z$ structural plane. The EBSD data have been collected through a whole thin section considering one measurement per grain. The isocontours are multiples of uniform distribution (MUD) using a linear distribution with a kernel Gaussian half-width angle of $10^{\circ} . N=$ number of grains, $J=$ texture index (Bunge, 1982), and $M=$ misorientation index (Skemer et al., 2005). (b) Distribution of uncorrelated misorientation angles of the respective quartz LPO shown in Figure 11 a. The $M_{\text {index }}$ is calculated from this distribution with respect to the theoretical distribution of a random LPO (dotted line; Skemer et al., 2005). (c) Distribution of the $J$ (solid bars) and $M$ (empty bars) indices across the strain gradient, that is, from grade 0 to grade 5. 


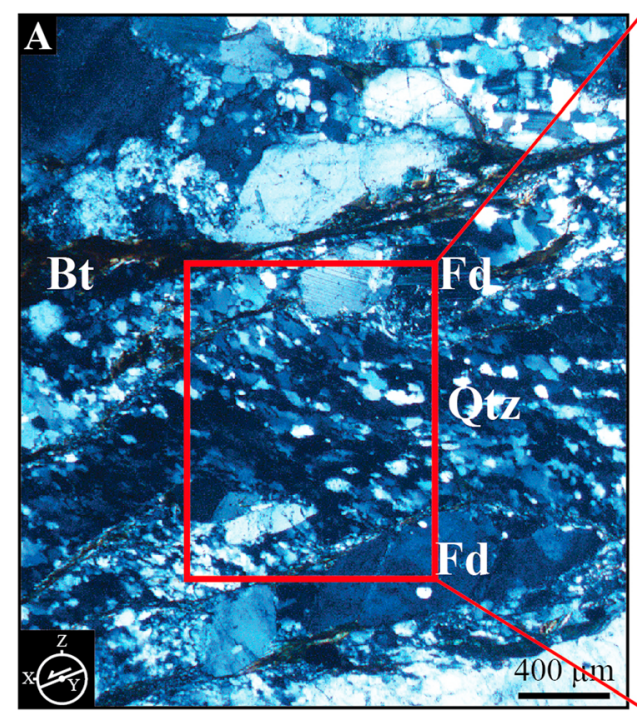

C

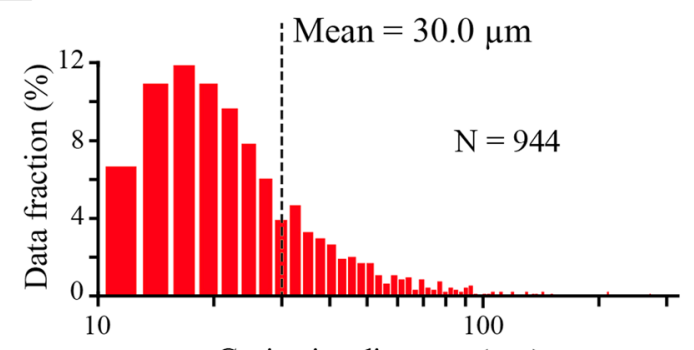

Grain size diameter $(\mu \mathrm{m})$

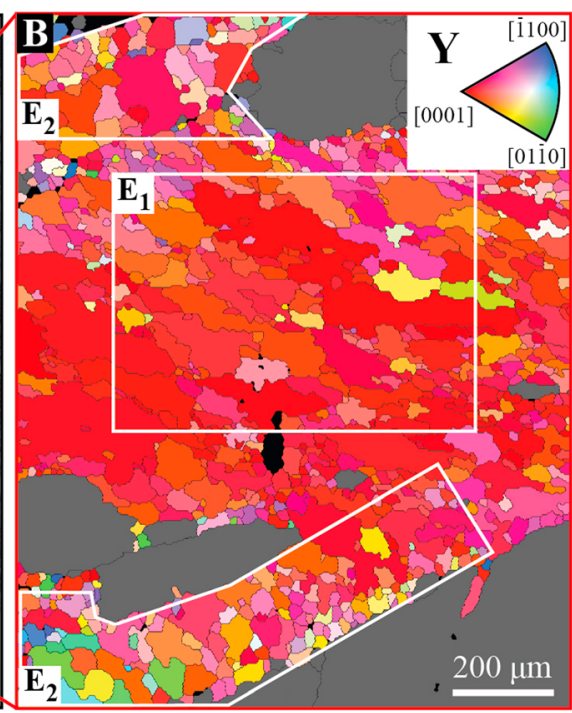

D $\quad c[0001]$

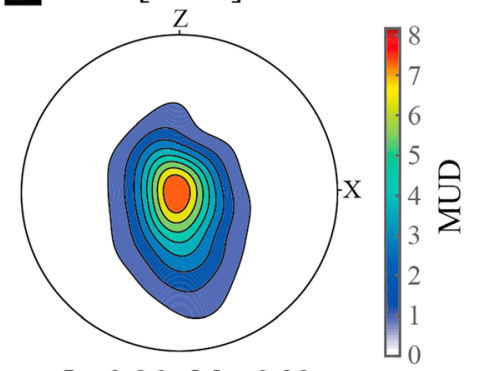

$\mathrm{J}=3.86 \mathrm{M}=0.29$
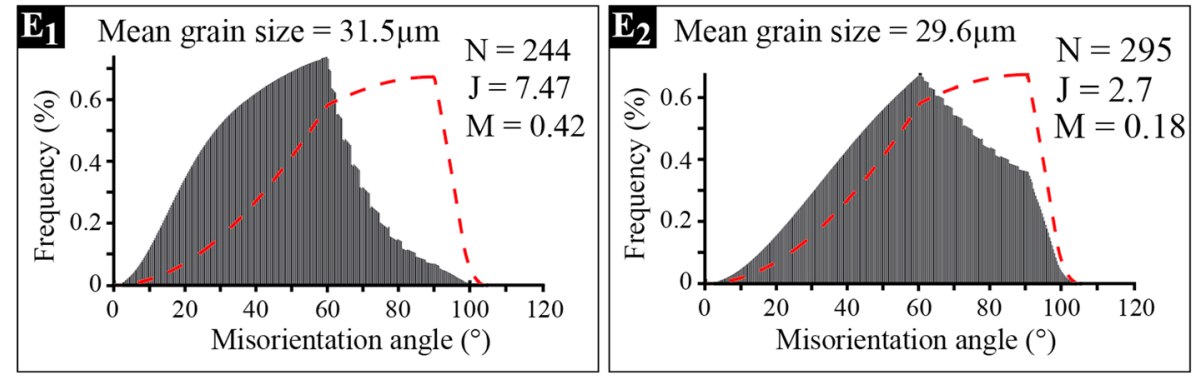

Figure 12. Quartz-related microstructures in high-strain shear bands. (a) Thin section (polarized light) of a shear band in the $X Z$ plane (in grade 4). Fd, Feldspar, QZ, quartz, and Bt, Biotite. (b) EBSD map combined with inverse pole figure (IPF map) with respect to the $Y$ axis (top right inset), that is, the deformation axis normal to the lineation in the foliation plane (location in Figure 12a). The color coding refers to the angle of one given axis with respect to $Y$. While the grey areas correspond to feldspar grains, the black areas give areas of nonindexed points. (c) Bar graph of the grain size distribution for quartz, highlighting a lognormal distribution with a mean grain size of $30 \mu \mathrm{m} . N=$ number of grains. (d) LPO of the quartz [c] axis considering one point per grain (mean orientation). The isocontours and color coding are multiples of a uniform distribution (MUD). J, texture index and $M$, misorientation index. (e) Bar graphs of uncorrelated misorientation angle distribution for two specific areas located in Figure 12b. While the grain size slightly decreases from area E1 $(31.5 \mu \mathrm{m})$ to area E2 $(29.6 \mu \mathrm{m})$, the mineral alignment strength $(J$ and $M$ indices) significantly drops and the angle distribution gets close to the uniform distribution (dotted red line). $N=$ number of grains.

stage 1 syn-magmatic pervasive shape fabric by an incipient localized shearing marked by proto-shear bands and beginning of ferromagnesian mineral concentrations.

Stage 3 is marked by an increasing anisotropy, from a $P^{\prime} \sim 1.13$ to $P^{\prime} \sim 1.25$, while the shape parameter $(T)$ remains plano-linear. This is correlated with a generalized nucleation of shear bands associated with the mineral reorientation of amphibole and biotite and quartz ribbons development wrapping around feldspar clasts with rare cataclasites (Figure $8 \mathrm{~d}$ ).

Stage 4 is characterized by a shape fabric eccentricity $P^{\prime}$ that evolves from 1.25 (stage 3) to 1.58 and a $T$ parameter that expresses a strong oblate shape. This final stage is characterized by the densification of 

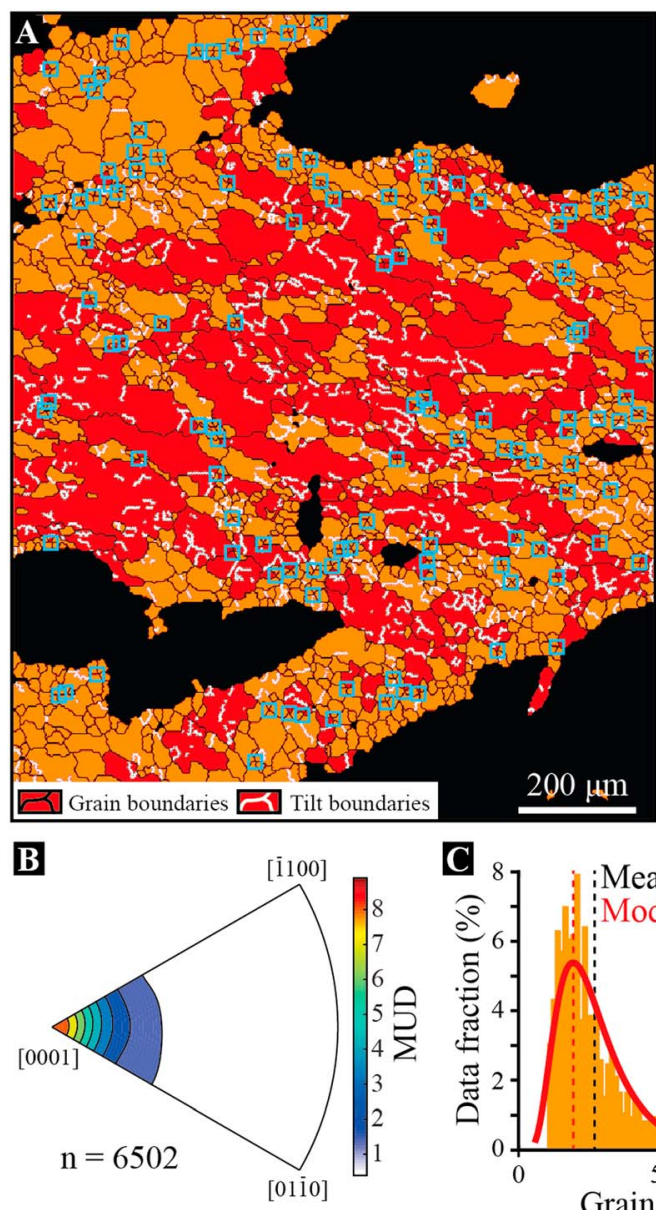
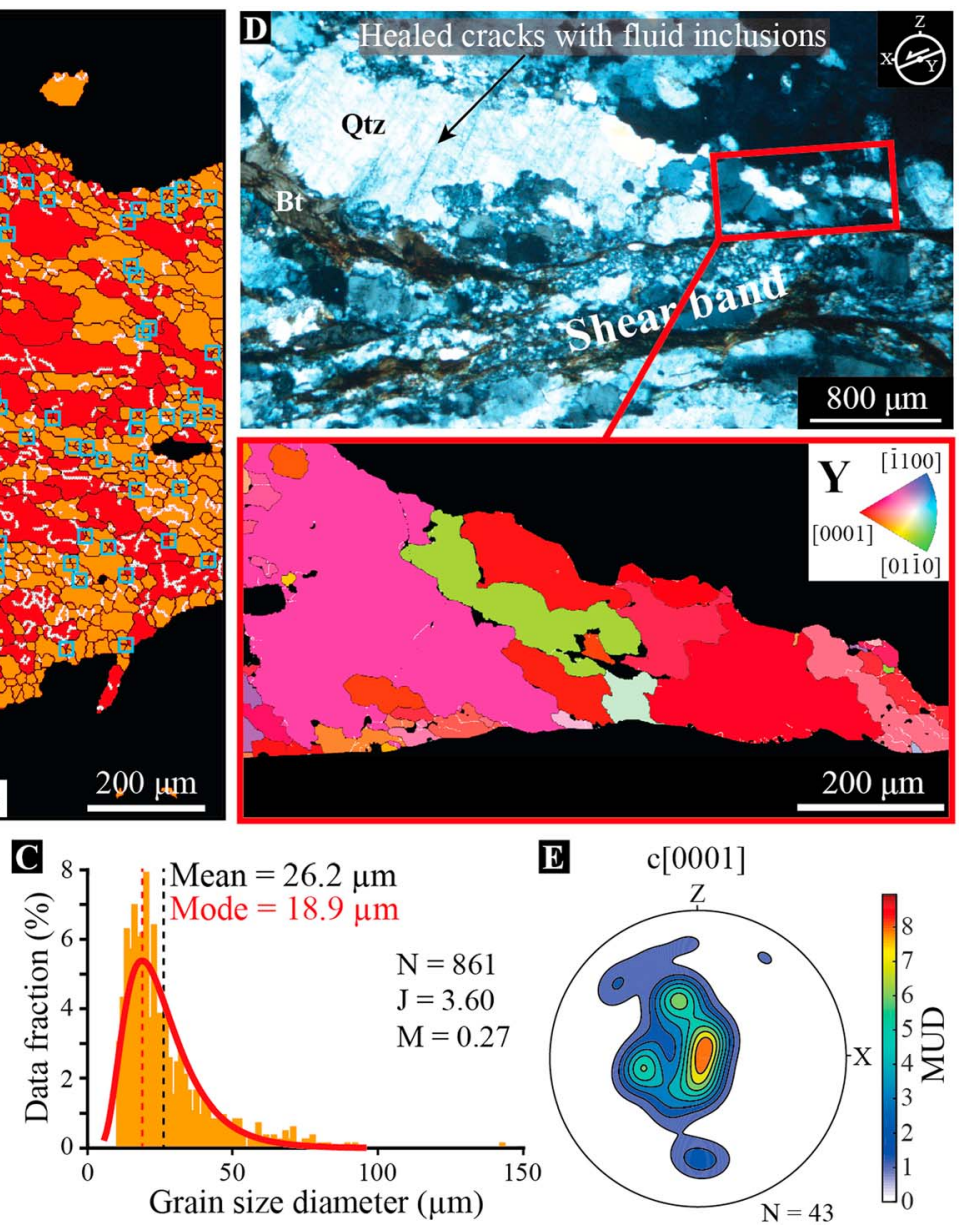

Figure 13. Grain boundaries and tilt boundaries of quartz aggregates in shear bands and recrystallized tails. (a) Phase map of the high-strain shear band shown in Figure 12, including quartz porphyroclasts (red) and recrystallized grains (orange). While grain boundaries (black lines) are defined by correlated misorientation angles higher than $10^{\circ}$, the tilt boundaries (white lines) refer to correlated misorientation angles between 2 and $10^{\circ}$. The blue empty squares highlight four-grain junctions (121). Black areas correspond to other phases and nonindexed points. (b) Inverse pole figure showing the distribution of rotation axes related to tilt boundaries in quartz aggregates. The concentration of misorientation axes around the $c[0001]$ axis indicates that subgrain boundaries are tilt boundaries that result from dislocation glide on the $\{m\}<a>$ slip system (Lloyd, 2004), coherent with prism $<a>$ slip LPO. (c) Grain size distribution of recrystallized grains. While the mean grain size $(26.6 \mu \mathrm{m})$ is calculated using the bar graph distribution, we applied a lognormal distribution to calculate the mode (18.9 $\mu \mathrm{m})$. (d) Thin section (polarized light) and EBSD map (IPF map) of quartz grains and tilt boundaries through a recrystallized tail by a high-strain shear band. Unlike to quartz-rich shear bands, we document lobate boundaries and a few tilt boundaries (see text). (e) Quartz c[0001] axis pole figure for the map in Figure 13d. The isocontours and color coding are multiples of uniform distribution (MUD). $N$, number of grains, $J=$ texture index, and $M$, misorientation index.

shear bands that often become tickers compared to those observed in stage 3 . In those bands, the mylonitic fabric is generalized with local cataclasis of quartz ribbons (Figures $8 \mathrm{e}$ and $8 \mathrm{f}$ ). At this stage, there is no evidence of locally preserved initial, magmatic to late-magmatic fabrics developed during the two first stages.

To summarize this analysis, stage 1 corresponds to a syn-magmatic fabric development while stage 2 can be assimilated to a first step of strain localization under very late magmatic to solid-state ductile conditions. Stage 3 corresponds to the development of a more pervasive network of centimeter scale anastomosed shear bands in ductile conditions. Stage 4 represents the generalization of a pervasive mylonitic shearing with local ultramylonitic to cataclasite, therefore brittle, textures.

A similar gradient was observed by Laurent et al. (2015) by using similar field and analytical approaches in the Ikaria syntectonic intrusion. The authors showed the same evolution from a linear magmatic fabric with a very low degree of anisotropy, about 10\%, toward mylonitic facies characterized by a very high degree of anisotropy. 


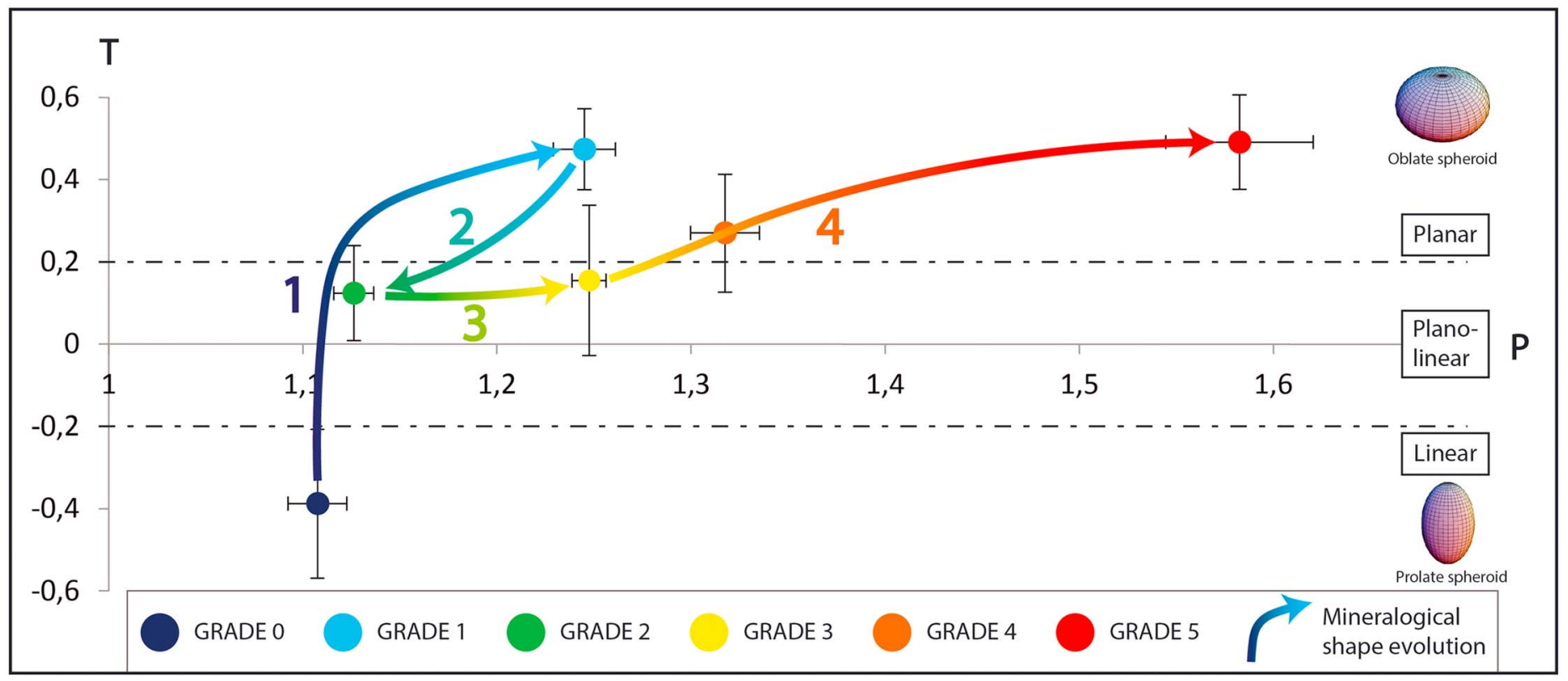

Figure 14. Interpreted shape parameter $(T)$ versus anisotropic degree $\left(P^{\prime}\right)$ diagram of the strain pattern evolution in the Naxos monzogranite. Colored dots correspond to the arithmetic average and associated standard deviation for each grade. Colored arrows correspond to the different stages of the deformation path discussed in the text.

\subsection{A Continuum of Deformation}

The four stages previously proposed to describe the evolution of the mineral fabrics and the development of discrete structures is based on local analyses and sampling along the gradient zone. Field observations realized on the Naxos intrusion of the deformation from syn-magmatic conditions to solid-state ductile, locally brittle reveal a continuum through the strain gradient zone (Figures 6 and 7). The Naxos intrusion recorded a strong gradient of deformation progressively localizing along the north dipping detachment, preserving a magmatic fabric in the southern part of the intrusion body. This succession of events, consistent with kinematics recorded within the metamorphic dome, shows that the MCC, together with the intrusion and associated detachments, developed coevally and represents different sequential events in the same extensional event.

The magmatic foliations preserved in the center areas of the intrusion are subvertical (Figure 2a). They evolve toward a horizontal orientation in zones that correspond to grade 2. The map of stretching lineations (Figure $2 \mathrm{~b}$ ) shows a progressive rotation from the $\mathrm{N} 10^{\circ}$ oriented lineation to the $\mathrm{N} 340^{\circ}$ trending one in the northern part of the intrusion, suggesting that the stretching lineation in the south is, at least partly, due to shearing related to regional extension.

An evolution from a linear to a planar shape fabric characterizes grade 1 of deformation (Figures 10 and 14) and is interpreted as the switch between a more pronounced SPO of amphibole and biotite grains. Grade 1 is also marked by the presence of fractures in stretched K-feldspars (Figure $8 \mathrm{~b}$ ). This type of structures is a response to a deformation at subsolidus state and requires a sufficiently high shearing stress applied on a cooling magma comprising 10 to 30\% of residual liquid (Bouchez et al., 1992; Paterson et al., 1989). Quartz, biotite, and hornblende that crystalized in the fractures affecting the feldspar megacrysts are the expression of this residual liquid. Bouchez et al. (1992) set prerequisites to consider such structures as late-magmatic microfractures. First, each microfracture should affect only one crystal and never overlap more. Then, mineral phases filling the fracture are crystallographically continuous and do not appear to change in their chemical composition. Finally, we observe that the filling phases are quartz, biotite, and hornblende (Figure 8b), which correspond to the magmatic paragenesis of the intrusion. Moreover, they tend to gradually disappear as the later solid-state deformation becomes more intense and overprints this submagmatic deformation. All of these elements show that the Naxos monzogranite is a syntectonic intrusion.

Then, the intensity of finite deformation drastically increases approaching the northern contact and the detachment (Figures 6 and 7). Indeed, at Aghios Prokopios peninsula, the transition from proto-mylonitic 

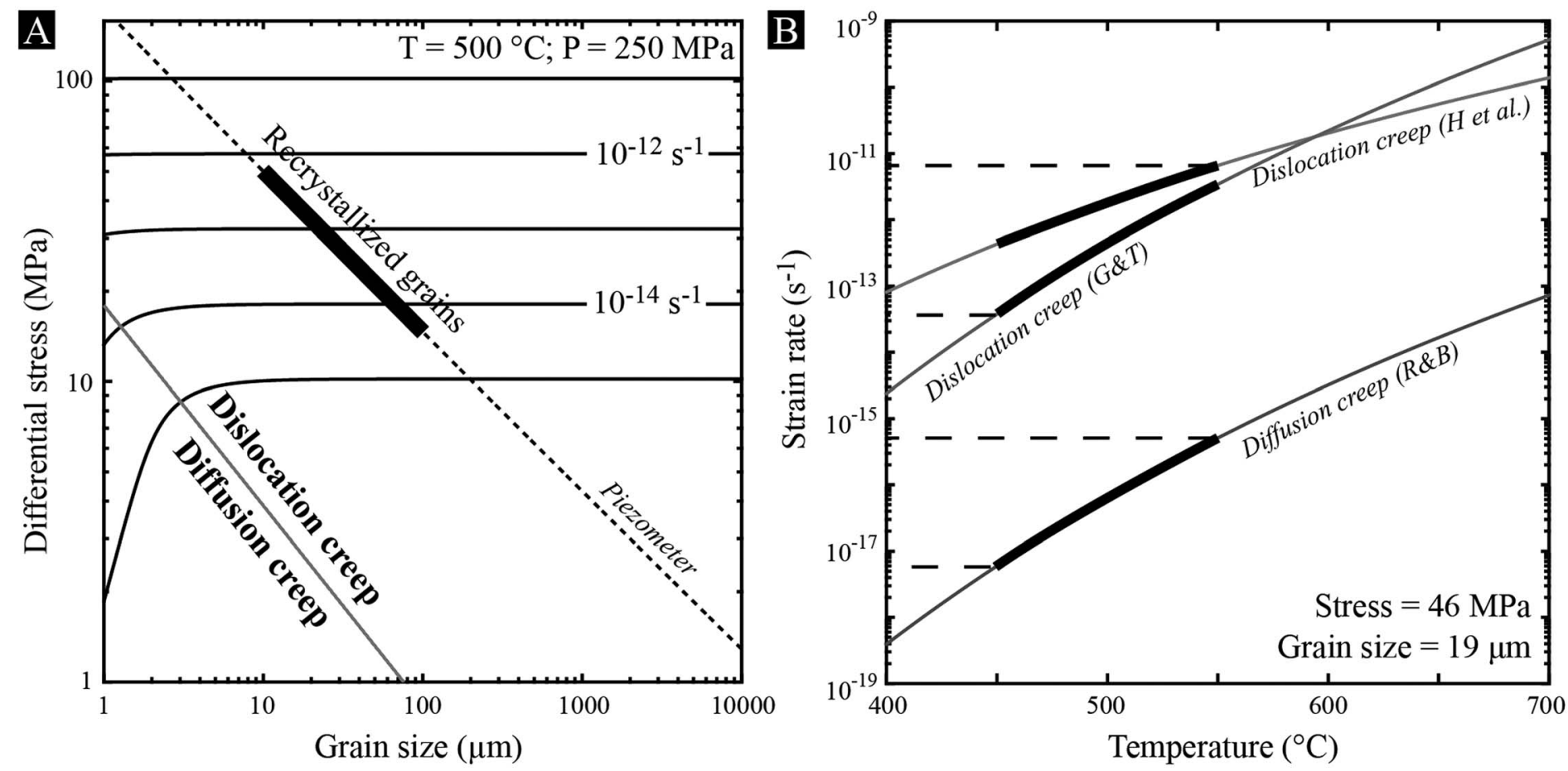

Figure 15. (a) Deformation mechanism map for wet quartz at $500^{\circ} \mathrm{C}$ and $250 \mathrm{MPa}$. The flow laws for dislocation creep and diffusion creep are from Gleason and Tullis (1995) and Rutter and Brodie (2004), respectively. Based on the quartz piezometer (Stipp \& Tullis, 2003 corrected by Holyoke \& Kronenberg, 2010) and using the size of recrystallized grains in high-strain shear bands (10-100 $\mu \mathrm{m}$ ), we predict predominant dislocation creep for high-strain shear bands of grade 4. (b) Predicted strain rates (black thick lines) of quartz aggregates as a function of temperature considering either dislocation creep (including the flow law from Hirth et al., 2001) or diffusion creep. For calculations, we used the mode of recrystallized grains $(\sim 19 \mu \mathrm{m})$ and a stress of $46 \mathrm{MPa}$, such as predicted by the piezometer. For the flow law of Hirth et al. (2001), we applied a water fugacity of $87 \mathrm{MPa}$ using the equation of state from Pitzer and Sterner (1994) at 500 ${ }^{\circ} \mathrm{C}$ and $250 \mathrm{MPa}$. Considering temperatures between 450 and $550^{\circ} \mathrm{C}$, as deduced from quartz mineral alignment in high-strain shear bands, we only predict realistic strain rates $\left(4.10^{-14}-7.10^{-12} \mathrm{~s}^{-1}\right)$ for dislocation creep, excluding diffusion creep as a source for grain boundary sliding (see text).

to mylonitic and even ultramylonitic fabric is achieved within only $500 \mathrm{~m}$ with a clear evolution of the degree of anisotropy and also a change from a plano-linear to a strongly planar fabric (Figures 7, 10, and 14). Furthermore, measured orientation of the shear planes appear to be parallel to the main detachment plane. Stretching lineations always oriented north-south and the overall top-to-the-north sense of shear are comparable with those measured in the dome.

The last increments of deformation in the Naxos intrusion comprise brittle deformation with ultracataclasites, pseudotachylites, or late steeply dipping normal faults. Cataclasites are positioned structurally within the highest grade of ductile deformation with an unclear transition as shown above (Figures 6 and 7), and they are topped by the detachment. They are characterized by a large thickness around several tens of meters, up to $50 \mathrm{~m}$ at Cape Achapsi where they are strongly chloritized and where two facies can be distinguished, a coarse-grained and fine-grained one. Finally, pseudotachylites veins develop along small-scale ultramylonitic shear planes near the detachment, reflecting a sudden and rapid acceleration of the local strain rate. The development of pseudotachylites is the logical continuation of the same deformation in the brittle, but it could also be part of a more recent deformation episode.

All of these deformation stages show a progressive evolution from magmatic to submagmatic, ductile, and then brittle deformation. This evolution demonstrates that the Naxos intrusion emplaced during top-to-the north shearing and started to be deformed while it remained about 10 to $30 \%$ of residual magmatic liquids in the crystallizing magma below a top-to-the north shallow-dipping shear zone.

\subsection{Deformation Mechanisms and Strain Localization}

The development of shear zone typically arises from strain localization during ductile deformation. In this regime, strain is accommodated by plastic processes that involve several competing deformation mechanisms, which dominant conditions depend on temperature, strain rate, stress, and grain size (Figure 15). For 
quartz in fully plastic conditions, two deformation mechanisms have been mainly considered so far: dislocation creep and diffusion creep (Bürgmann \& Dresen, 2008; Gleason \& Tullis, 1995; Hirth et al., 2001). While dislocation creep refers to plastic flow achieved by lattice-controlled migration of intragranular line defects (dislocations), diffusion creep involves the diffusion of vacancies through the crystal lattice. These two mechanisms may also combine with grain boundary sliding depending on the deformation conditions (Boullier \& Gueguen, 1975; Kilian et al., 2011; Kruse \& Stünitz, 1999; Mehl \& Hirth, 2008; Rahl \& Skemer, 2016; Stünitz \& Fitzgerald, 1993). Unlike dislocation creep, both diffusion creep and grain boundary sliding are dependent on grain size, which may promote a drop of viscosity during grain size reduction, giving rise to a rheological weakening and possibly strain localization (De Bresser et al., 2001; Platt \& Behr, 2011).

When diffusion creep is dominant, it commonly relates to a weak or absent LPO. In contrast, a dominant dislocation creep produces a strong LPO (Baker \& Wenk, 1972), a strong SPO (Stipp et al., 2002), and new recrystallized grains, which size mostly depends on stress conditions (Austin \& Evans, 2007; Stipp \& Tullis, 2003). Natural observations and experimental investigations have also shown that both the process of dynamic recrystallization and the pattern of recrystallized quartz LPO directly depend on strain rate, finite strain, and temperature during dislocation creep (Hirth \& Tullis, 1992; Stipp et al., 2002). With increasing temperature (or decreasing strain rate), the type of recrystallization changes from bulging recrystallization to subgrain rotation and then to a combination of both mechanisms due to efficient grain boundary migration, which becomes dominant above $500^{\circ} \mathrm{C}$ (Hirth \& Tullis, 1992). In relation to this, the pattern of recrystallized quartz LPO switches from dominant basal $<a>$ slip LPO at low temperature-in combination with other slip systems (basal, rhomb, and prism) - to dominant prism $<a>$ slip LPO at high temperature. The transition has been estimated around $500^{\circ} \mathrm{C}$, but this value may also change depending on the finite strain involved (Stipp et al., 2002).

In Naxos, the presence of an SPO and a moderate to strong prism $<a>$ slip LPO combined with microstructural evidence of subgrain boundaries and recrystallized tails of quartz supports dominant dislocation creep through the whole studied intrusion. It further indicates high-temperature deformation above $500^{\circ} \mathrm{C}$, but the evolution toward multiple slip systems with increasing strain, as shown by girdle development, and the occurrence of brittle deformation in grade 5 suggest that deformation also occurred down to $\sim 350^{\circ} \mathrm{C}$ in high-strain grades. The occurrence of lobate grain boundaries is also indicative of significant grain boundary migration during deformation (Heilbronner \& Tullis, 2006; Hirth \& Tullis, 1992), and probably in presence of fluids, such as deduced from the presence of strain-related fluid inclusions. However, although quartz LPO never fully randomizes, we document a drop of overall mineral alignment strength with increasing strain (Figure 11). This feature contradicts lab-based experiments that always documented an increasing LPO with increasing strain when dislocation creep is dominant (Hansen et al., 2014; Heilbronner \& Tullis, 2006; Mainprice et al., 2015). As one possibility, such a drop could be an effect of dynamic recrystallization (Hirth \& Tullis, 1992), but recent deformation experiments of polycrystal quartzite have shown that quartz LPO significantly strengthens with increasing degree of dynamic recrystallization (Heilbronner \& Tullis, 2006). Another possibility implies the overprinting of a previous mineral alignment by a new one, such as highlighted by our SPO data set. In this case, grade 0 may have been affected by grades 1 and 2 during a former stage of deformation, and then grades 3 to 5 may result from latter stages of strain localization, but with different orientations of the deformation axes. Nonetheless, although we do not exclude this effect, our data set does not show any combined patterns of quartz LPO, and it does not account for the drop of mineral alignment strength between grades 3 and 4 .

Alternatively, the large amount of four-grain junctions indicates that grain boundary sliding has significantly contributed to the deformation (Ree, 1994). Previous documentations of quartz-rich mylonite have shown indeed that grain size-sensitive creep, including grain boundary sliding, may occur during dynamic recrystallization in presence of fluids (Halfpenny et al., 2006; Rahl \& Skemer, 2016). This would account for the progressive drop of overall mineral alignment strength with increasing strain, that is, with increasing degree of recrystallization and related grain size reduction. The quartz LPO might also locally weaken depending on the degree of dynamic recrystallization or local amount of fluid at grain boundaries, such as expected in high-strain shear bands. We would finally expect a strengthening of quartz LPO in grade 5 if we consider that most of the rock has achieved $100 \%$ of recrystallization. Our LPO features indicate therefore that grain boundary sliding probably occurred in combination with dislocation creep during deformation of the Naxos shear zone. Together with grain size reduction, this provides a consistent approach to account for the occurrence of weakening and subsequent strain localization across the intrusion. 
Nevertheless, the source of grain boundary sliding in Naxos remains a fundamental issue. Based on available flow laws (Gleason \& Tullis, 1995; Hirth et al., 2001; Rutter \& Brodie, 2004) and using the mode of recrystallized grain size $(\sim 19 \mu \mathrm{m})$ to estimate the differential stress (Stipp \& Tullis, 2003 corrected by Holyoke \& Kronenberg, 2010), we predict dislocation creep as dominating the rheology of the high-strain shear bands, and, by deduction, the rheology of the host rock, which necessarily stands above the piezometer (Figure 15a). We used the mode rather than the mean grain size to minimize the effect of porphyroclasts. Furthermore, while dominant dislocation creep implies realistic strain rates between $4.10^{-14}$ and $7.10^{-12} \mathrm{~s}^{-1}$ for a temperature ranging from 450 to $550^{\circ} \mathrm{C}$, dominant diffusion creep involves much slower and unrealistic strain rates $\left(5.10^{-18}-5.10^{-16} \mathrm{~s}^{-1}\right)$ in the same temperature conditions (Figure 15b). This definitely excludes diffusion creep as a source for grain boundary sliding, requiring an alternative mechanism.

On this base, we may envisage two possibilities that imply either dislocation-accommodated grain boundary sliding (disGBS) or pressure-solution creep (Hirth \& Kohlstedt, 2003; Gratier et al., 2013). These two mechanisms are indeed grain size dependent, and they involve, or combine with, grain boundary sliding. However, although disGBS has been only highlighted and quantified for olivine aggregates (Hirth \& Kohlstedt, 2003), (1) it never arises in the presence of fluids, (2) it results in a strong crystal preferred orientation, the strength of which increases with increasing strain (Hansen, Zimmerman, \& Kohlstedt, 2012), and (3) its grain size dependency is not sufficient to promote strain localization (Gueydan \& Précigout, 2014). DisGBS does not seem therefore to be the best candidate to account for the microstructural features and strain localization in Naxos. In contrast, the highly grain-size-sensitive pressure-solution creep, which is conditional upon the presence of fluids, would represent an appropriate candidate. But here more data and evidence of dissolution-precipitation are needed to go further in the discussion.

\section{Conclusion}

This study gives information on the emplacement mechanisms and subsequent exhumation deformation about the Naxos intrusion. Using field structural data associated with EBSD, 2-D, and 3-D textural and structural analyses, we document a rapid evolution of the deformation gradient approaching the major detachment along the northern border of the intrusion. At both macroscopic and microscopic scales, stress related to the emplacement of the intrusion first guides the development of a magmatic shape fabric of amphibole and biotite grains. During the activity of the detachment, the preexisting localization of the deformation linked with the intrusion emplacement played also an important role in the localization of the deformation and the development of the shearing structures.

The continuum of deformation from magmatic to solid-state ductile-then-brittle conditions is characterized by a persistent stretching direction and the development of an anastomosed network of discrete shear bands that evolves to a penetrative mylonitic texture approaching the detachment fault. All together, these features indicate that the Naxos intrusion recorded a strong gradient of deformation that progressively localized along the north dipping detachment during its emplacement. This accounts for the preservation of a magmatic fabric in the core of the intrusion. This succession of events is also consistent with the top-to-the-N kinematics within the neighboring Naxos metamorphic dome. This clearly demonstrates that the MCC together with the intrusion and associated detachments developed coevally, recording different sequential steps within a single crustal-scale extensional event. Furthermore, microstructural features indicate that plastic flow of the whole intrusion has been dominated by dislocation creep from more than $500^{\circ} \mathrm{C}$ to $\sim 350^{\circ} \mathrm{C}$ (ductile-to-brittle transition). However, numerous four-grain junctions also indicate a significant contribution of grain boundary sliding, in combination with dislocation creep. Together with grain size reduction induced by dynamic recrystallization, this grain size sensitive mechanism provides a good candidate to account for strain localization in Naxos. Nevertheless, the source of grain boundary sliding remains to be better constrained.

This study is a contribution of the ERC REOLITH Project (ERC Advanced grant 290864). Data set is available, in open access, at https://zenodo.org/record/ 887184. We gratefully acknowledge the reviewer, Andrew Cross, for his constructive and insightful comments and suggestions that contributed to improve the quality of the manuscript. Our gratitude is also extended to Editor, Claudio Faccenna, and the Associate Editor who provided additional helpful comments.

\section{References}

Acocella, V., \& Rossetti, F. (2002). The role of extensional tectonics at different crustal levels on granite ascent and emplacement: An example from Tuscany (Italy). Tectonophysics, 354(1-2), 71-83. https://doi.org/10.1016/S0040-1951(02)00290-1

Agard, P., Omrani, J., Jolivet, L., Whitechurch, H., Vrielynck, B., Spakman, W., ... Wortel, R. (2011). Zagros orogeny: A subduction-dominated process. Geological Magazine, 148(5-6), 692-725. https://doi.org/10.1017/S001675681100046X

Altherr, R., Kreuzer, H., Wendt, I., Lenz, H., Wagner, G. A., Keller, J., ... Hohndorf, A. (1982). A late Oligocene/early Miocene high temperature belt in the Attic-Cycladic crystalline complex (SE Pelagonian, Greece). Geologisches Jahrbuch, 23, 97-164.

Altherr, R., Schliestedt, M., Okrusch, M., Seidel, E., Kreuzer, H., Harre, W., ... Wagner, G. A. (1979). Geochronology of high-pressure rocks on Sifnos (Cyclades, Greece). Contributions to Mineralogy and Petrology, 70(3), 245-255. https://doi.org/10.1007/BF00375354 
Altherr, R., \& Siebel, W. (2002). I-type plutonism in a continental back-arc setting: Miocene granitoids and monzogranites from the central Aegean Sea, Greece. Contributions to Mineralogy and Petrology, 143(4), 397-415. https://doi.org/10.1007/s00410-002-0352-y

Andriessen, P. A. M., Banga, G., \& Hebeda, E. H. (1987). Isotopic age study of pre-Alpine rocks in the basal units on Naxos, Sikinos and los, Greek Cyclades. Geologie en Mijnbouw, 66(3), 3-14.

Andriessen, P. A. M., Boelrijk, N. A. I. M., Hebeda, E. H., Priem, H. N. A., Verdurnen, E. A. T., \& Verschure, R. H. (1979). Dating the events of metamorphism and granitic magmatism in the Alpine orogen of Naxos (Cyclades, Greece). Contributions to Mineralogy and Petrology, 69(3), 215-225. https://doi.org/10.1007/BF00372323

Augier, R., Jolivet, L., Gadenne, L., Lahfid, A., \& Driussi, O. (2015). Exhumation kinematics of the Cycladic blueschists unit and back-arc extension, insight from the southern Cyclades (Sikinos and Folegandros Islands, Greece). Tectonics, 34, 152-185. https://doi.org/10.1002/ 2014TC003664

Austin, N. J., \& Evans, B. (2007). Paleowattmeters: A scaling relation for dynamically recrystallized grain size. Geology, 35(4), 343-346. https:// doi.org/10.1130/G23244A.1

Avigad, D. (1998). High-pressure metamorphism and cooling on SE Naxos (Cyclades, Greece). European Journal of Mineralogy, 10(6), 1309-1320. https://doi.org/10.1127/ejm/10/6/1309

Bachmann, F., Hielscher, R., \& Schaeben, H. (2010). Texture analysis with MTEX-free and open source software toolbox. In Solid State Phenomena, 160, 63-68. https://doi.org/10.4028/www.scientific.net/SSP.160.63

Baker, D. R., Mancini, L., Polacci, M., Higgins, M. D., Gualda, G. A. R., Hill, R. J., \& Rivers, M. L. (2012). An introduction to the application of X-ray microtomography to the thrre-dimensional study of igneous rocks. Lithos, 148, 262-276. https://doi.org/10.1016/j.lithos.2012.06.008

Baker, D. W., \& Wenk, H. (1972). Preferred orientation in the low symmetry quartz mylonite. Journal of Geology, 80(1), 81-105. https://doi.org/ $10.1086 / 627714$

Baldwin, S. L., Lister, S., Hill, E. J., Foster, D. A., \& McDougall, I. (1993). Thermochronologic constraints on the tectonic evolution of active metamorphic core complexes, D'entrecasteaux Islands, Papua New Guinea. Tectonics, 12(3), 611-628. https://doi.org/10.1029/93TC00235

Bargnesi, E. A., Stockli, D. F., Mancktelow, N., \& Soukis, K. (2013). Miocene core complex development and coeval supradetachment basin evolution of Paros, Greece, insights from (U-Th)/He thermochronometry. Tectonophysics, 595-596, 165-182. https://doi.org/10.1016/j. tecto.2012.07.015

Blake, M. C., Bonneau, M., Geyssant, J., Kienast, J. R., Lepvrier, C., Maluski, H., \& Papanikolaou, D. (1981a). A geologic reconnaissance of the Cycladic blueschist belt, Greece. Geological Society of America Bulletin, 92(5), 247-254. https://doi.org/10.1130/0016-7606(1981)92\% 3C247:AGROTC\%3E2.0.CO;2

Blake, M. C., Bonneau, M., Geyssant, J., Kienast, J. R., Lepvrier, C., Maluski, H., \& Papanikolaou, D. (1981b). A geologic reconnaissance of the Cycladic blueschist belt, Greece: Discussion and reply. Geological Society of America Bulletin, 95(1), 119-121.

Böger, H. (1983). Stratigraphische und tektonische Verknupfungen kontinentaler Sedimente des Neogens Ägäis-Raum. Geologische Rundschau, 72, 771-814.

Bolhar, R., Ring, U., \& Allen, C. M. (2010). An integrated zircon geochronological and geochemical investigation into the Miocene plutonic evolution of the Cyclades, Aegean Sea, Greece: Part 1: Geochronology. Contributions to Mineralogy and Petrology, 160(5), 719-742. https:// doi.org/10.1007/s00410-010-0504-4

Bonneau, M. (1984). Correlation of the Hellenide nappes in the south-east Aegean and their tectonic reconstruction. Geological Society of London Special Publication, 17(1), 517-527. https://doi.org/10.1144/GSL.SP.1984.017.01.38

Bonneau, M., \& Kienast, J. R. (1982). Subduction, collision et schistes bleus: L'exemple de l'Egée (Grèce). Bulletin de la Societe Geologique de France, 24, 785-791.

Borradaile, G. J., \& Werner, T. (1994). Magnetic anisotropy of some phyllosilicates. Tectonophysics, 235(3), 223-248. https://doi.org/10.1016/ 0040-1951(94)90196-1

Bouchez, J. L., Delas, C., Gleizes, G., Nédélec, A., \& Cuney, M. (1992). Submagmatic microfractures in granites. Geology, 20(1), 35-38. https:// doi.org/10.1130/0091-7613(1992)020\%3C0035:SMIG\%3E2.3.CO;2

Boullier, A. M., \& Gueguen, Y. (1975). SP-mylonites: Origin of some mylonites by superplastic flow. Contributions to Mineralogy and Petrology, 50(2), 93-104. https://doi.org/10.1007/BF00373329

Brichau, S., Ring, U., Carter, A., Bolhar, R., Monié, P., Stockli, D., \& Brunel, M. (2008). Timing, slip rate, displacement and cooling history of the Mykonos detachment footwall, Cyclades, Greece, and implications for the opening of the Aegean Sea basin. Journal of the Geological Society, 165(1), 263-277. https://doi.org/10.1144/0016-76492006-145

Brichau, S., Ring, U., Carter, A., Monié, P., Bolhar, R., Stockli, D., \& Brunel, M. (2007). Extensional faulting on Tinos island, Aegean Sea, Greece: How many detachments? Tectonics, 26, TC4009. https://doi.org/10.1029/2006TC001969

Brichau, S., Ring, U., Ketcham, R. A., Carter, A., Stockli, D., \& Brunel, M. (2006). Constraining the long-term evolution of the slip rate for a major extensional fault system in the central Aegean, Greece, using thermochronology. Earth and Planetary Science Letters, 241(1-2), 293-306. https://doi.org/10.1016/j.epsl.2005.09.065

Brichau, S., Thomson, S., \& Ring, U. (2010). Thermochronometric constraints on the tectonic evolution of the Serifos detachment, Aegean Sea, Greece. International Journal of Earth Sciences, 99(2), 379-393. https://doi.org/10.1007/s00531-008-0386-0

Bröcker, M., \& Enders, M. (1999). U-Pb zircon geochronology of unusual eclogite-facies rocks from Syros and Tinos (Cyclades, Greece). Geological Magazine, 136(2), 111-118. https://doi.org/10.1017/S0016756899002320

Brown, M. (1994). The generation, segregation, ascent and emplacement of granite magma: The migmatite-to-crustally-derived granite connection in thickened orogens. Earth-Science Reviews, 36(1-2), 83-130. https://doi.org/10.1016/0012-8252(94)90009-4

Brun, J.-P., \& Faccenna, C. (2008). Exhumation of high-pressure rocks driven by slab rollback. Earth and Planetary Science Letters, 272(1-2), 1-7. https://doi.org/10.1016/j.epsl.2008.02.038

Buick, I. S. (1991a). Mylonite fabric development on Naxos, Greece. Journal of Structural Geology, 13(6), 643-655. https://doi.org/10.1016/ 0191-8141(91)90027-G

Buick, I. S. (1991b). The late Alpine evolution of an extensional shear zone, Naxos, Greece. Journal of the Geological Society, 148(1), 93-103. https://doi.org/10.1144/gsjgs.148.1.0093

Bunge, H. J. (1982). Inhomogeneous textures. Zeitschrift für Metallkunde, 73(8), 483-488.

Bürgmann, R., \& Dresen, G. (2008). Rheology of the lower crust and upper mantle: Evidence from rock mechanics, geodesy, and field observations. Annual Review of Earth and Planetary Sciences, 36(1), 531-567. https://doi.org/10.1146/annurev.earth.36.031207.124326

Cao, S., Neubauer, F., Bernroider, M., Genser, J., Liu, J., \& Friedl, G. (2016). Low-grade retrogression of a high-temperature metamorphic core complex: Naxos, Cyclades, Greece. Geological Society of America Bulletin, 129(1-2), 93-117, B31502.1. https://doi.org/10.1130/B31502.1

Charles, N., Augier, R., Gumiaux, C., Monié, P., Chen, Y., Faure, M., \& Zhu, R. (2013). Timing, duration and role of magmatism in wide rift systems: Insights from the Jiaodong Peninsula (China, East Asia). Gondwana Research, 24(1), 412-428. https://doi.org/10.1016/j.gr.2012.10.011 
Charles, N., Gumiaux, C., Augier, R., Chen, Y., Zhu, R., \& Lin, W. (2011). Metamorphic core complexes vs. synkinematic plutons in continental extension setting: Insights from key structures (Shandong Province, eastern China). Journal of Asian Earth Sciences, 40(1), 261-278. https:// doi.org/10.1016/j.jseaes.2010.07.006

Coney, P. J., \& Harms, T. A. (1984). Cordilleran metamorphic core complexes: Cenozoic extensional relics of Mesozoic compression. Geology, 12(9), 550-554. https://doi.org/10.1130/0091-7613(1984)12\%3C550:CMCCCE\%3E2.0.CO;2

Crittenden, M. D., Coney, P. J., \& Davis, G. H. (1980). Cordilleran metamorphic core complexes. Geological Society of America, 153. https://doi. org/10.1130/MEM153-p485

Daniel, J. M., \& Jolivet, L. (1995). Detachment faults and pluton emplacement: Elba Island (Tyrrhenian Sea). Bulletin de la Societe Geologique de France, 166, 341-341. https://doi.org/10.2113/gssgfbull.166.4.341

Davidson, C., Schmid, S. M., \& Hollister, L. S. (1994). Role of melt during deformation in the deep crust. Terra Nova, 6(2), 133-142. https://doi. org/10.1111/j.1365-3121.1994.tb00646.x

Davis, G. A., Fowler, T. K., Bishop, K. M., Brudos, T. C., Friedmann, S. J., Burbank, D. W., ... Burchfiel, B. C. (1993). Pluton pinning of an active Miocene detachment fault system, eastern Mojave Desert, California. Geology, 21(7), 627-630. https://doi.org/10.1130/00917613(1993)021\%3C0627:PPOAAM\%3E2.3.CO;2

De Bresser, J., Ter Heege, J., \& Spiers, C. (2001). Grain size reduction by dynamic recrystallization: Can it result in major rheological weakening? International Journal of Earth Sciences, 90(1), 28-45. https://doi.org/10.1007/s005310000149

Denèle, Y., Lecomte, E., Jolivet, L., Lacombe, O., Labrousse, L., Huet, B., \& Le Pourhiet, L. (2011). Granite intrusion in a metamorphic core complex: The example of the Mykonos laccolith (Cyclades, Greece). Tectonophysics, 501(1-4), 52-70. https://doi.org/10.1016/j.tecto.2011.01.013

D'lemos, R. S., Brown, M., \& Strachan, R. A. (1992). Granite magma generation, ascent and emplacement within a transpressional orogeny. Journal of the Geological Society, 149(4), 487-490. https://doi.org/10.1144/gsjgs.149.4.0487

Duchêne, S., Aïssa, R., \& Vanderhaeghe, O. (2006). Pressure-temperature-time evolution of metamorphic rocks from Naxos (Cyclades, Greece): Constraints from thermobarometry and Rb/Sr dating. Geodinamica Acta, 19(5), 301-321. https://doi.org/10.3166/ga.19.301-321

Faure, M., Bonneau, M., \& Pons, J. (1991). Ductile deformation and syntectonic granite emplacement during the late Miocene extension of the Aegean (Greece). Bulletin de la Societe Geologique de France, 162(1), 3-11. https://doi.org/10.2113/gssgfbull.162.1.3

Feenstra, A. (1985). Metamorphism of bauxites on Naxos, Greece (PhD thesis). Instituut voor Aardwetenschappen, Utrecht University Repository, Netherlands.

Gans, P. B., Mahood, G. A., \& Schermer, E. (1989). Synextensional magmatism in the Basin and Range Province; a case study from the eastern Great Basin. Geological Society of America Special Papers, 233, 1-53. https://doi.org/10.1130/SPE233-p1

Gautier, P., \& Brun, J. P. (1994a). Crustal-scale geometry and kinematics of late-orogenic extension in the central Aegean (Cyclades and Ewia Island). Tectonophysics, 238(1-4), 399-424. https://doi.org/10.1016/0040-1951(94)90066-3

Gautier, P., \& Brun, J. P. (1994b). Ductile crust exhumation and extensional detachments in the central Aegean (Cyclades and Evvia Islands). Geodinamica Acta, 7(2), 57-85. https://doi.org/10.1080/09853111.1994.11105259

Gautier, P., Brun, J.-P., \& Jolivet, L. (1993). Structure and kinematics of Upper Cenozoic extensional detachment on Naxos and Paros (Cyclades Islands, Greece). Tectonics, 12(5), 1180-1194. https://doi.org/10.1029/93TC01131

Gleason, G. C., \& Tullis, J. (1995). A flow law for dislocation creep of quartz aggregates determined with the molten salt cell. Tectonophysics, 247(1-4), 1-23. https://doi.org/10.1016/0040-1951(95)00011-B

Grasemann, B., \& Petrakakis, K. (2007). Evolution of the Serifos metamorphic core complex. Inside the Aegean core complexes. Journal of the Virtual Explorer, 27, 1-18.

Grasemann, B., Schneider, D. A., Stockli, D. F., \& Iglseder, C. (2012). Miocene bivergent crustal extension in the Aegean: Evidence from the western Cyclades (Greece). Lithosphere, 4(1), 23-39. https://doi.org/10.1130/L164.1

Gratier, J. P., Dysthe, D. K., \& Renard, F. (2013). The role of pressure solution creep in the ductility of the Earth's upper crust. Advances in Geophysics, 54, 47-179. https://doi.org/10.1016/B978-0-12-380940-7.00002-0

Gualda, G. A. R., \& Rivers, M. (2006). Quantitative 3D petrography using x-ray tomography: Application to Bishop Tuff pumice clasts. Journal of Volcanology and Geothermal Research, 154(1-2), 48-62. https://doi.org/10.1016/j.jvolgeores.2005.09.019

Gueydan, F., \& Précigout, J. (2014). Modes of continental rifting as a function ductile strain localization in the lithospheric mantle. Tectonophysics, 612-613, 18-25. https://doi.org/10.1016/j.tecto.2013.11.029

Halfpenny, A., Prior, D. J., \& Wheeler, J. (2006). Analysis of dynamic recrystallization and nucleation in a quartzite mylonite. Tectonophysics, 427(1-4), 3-14. https://doi.org/10.1016/j.tecto.2006.05.016

Hansen, L. N., Zhao, Y. H., Zimmerman, M. E., \& Kohlstedt, D. L. (2014). Protracted fabric evolution in olivine: Implications for the relationship among strain, crystallographic fabric, and seismic anisotropy. Earth and Planetary Science Letters, 387, 157-168. https://doi.org/10.1016/j. epsl.2013.11.009

Hansen, L. N., Zimmerman, M. E., \& Kohlstedt, D. L. (2012). The influence of microstructure on deformation of olivine in the grain-boundary sliding regime. Journal of Geophysical Research, 117, B09201. https://doi.org/10.1029/2012JB009305

Heilbronner, R., \& Tullis, J. (2006). Evolution of c axis pole figures and grain size during dynamic recrystallization: Results from experimentally sheared quartzite. Journal of Geophysical Research, 111, B10202. https://doi.org/10.1029/2005JB004194

Henjes-Kunst, F., Altherr, R., Kreuzer, H., \& Hansen, B. T. (1988). Disturbed U-Th-Pb systematics of young zircons and uranothorites: The case of the Miocene Aegean granitoids (Greece). Chemical Geology: Isotope Geoscience, 73(2), 125-145. https://doi.org/10.1016/01689622(88)90011-5

Henjes-Kunst, F., \& Kreuzer, H. (1982). Isotopic dating of pre-alpidic rocks from the island of los (Cyclades, Greece). Contributions to Mineralogy and Petrology, 80(3), 245-253. https://doi.org/10.1007/BF00371354

Hirth, G., \& Kohlstedt, D. L. (2003). Rheology of the upper mantle and the mantle wedge: A view from the experimentalists. In J. Eiler (Ed.), Inside the Subduction Factory, Geophysical Monograph Series (Vol. 138, pp. 83-105). Washington, DC: American Geophysical Union. https:// doi.org/10.1029/138GM06

Hirth, G., Teyssier, C., \& Dunlap, W. J. (2001). An evaluation of quartzite flow laws based on comparison between experimentally and naturally deformed rocks. International Journal of Earth Sciences, 90(1), 77-87. https://doi.org/10.1007/s005310000152

Hirth, G., \& Tullis, J. (1992). Dislocation creep regimes in quartz aggregates. Journal of Structural Geology, 14(2), 145-159. https://doi.org/ 10.1016/0191-8141(92)90053-Y

Holyoke, C. W., \& Kronenberg, A. K. (2010). Accurate differential stress measurement using the molten salt cell and solid salt assemblies in the Griggs apparatus with applications to strength, piezometers and rheology. Tectonophysics, 494(1-2), 17-31. https://doi.org/10.1016/j. tecto.2010.08.001

Huet, B., Labrousse, L., \& Jolivet, L. (2009). Thrust or detachment? Exhumation processes in the Aegean: Insight from a field study on los (Cyclades, Greece). Tectonics, 28, TC3007. https://doi.org/10.1029/2008TC002397 
Hutton, D. H. W. (1982). A tectonic model for the emplacement of the Main Donegal Granite, NW Ireland. Journal of the Geological Society, 139(5), 615-631. https://doi.org/10.1144/gsjgs.139.5.0615

Iglseder, C., Grasemann, B., Rice, A. H. N., Petrakakis, K., \& Schneider, D. A. (2011). Miocene south directed low-angle normal fault evolution on Kea Island (West Cycladic Detachment System, Greece). Tectonics, 30, TC4013. https://doi.org/10.1029/2010TC002802

Iglseder, C., Grasemann, B., Schneider, D. A., Petrakakis, K., Miller, C., Klötzli, U. S., ... Rambousek, C. (2009). I and S-type plutonism on Serifos (W-Cyclades, Greece). Tectonophysics, 473(1-2), 69-83. https://doi.org/10.1016/j.tecto.2008.09.021

Jansen, J. B. H. (1973). Geological map of Naxos (1/50 000). Nation. Inst. Geol. Mining Res., Athens.

Jansen, J. B. H. (1977). Metamorphism on Naxos, Greece (PhD thesis) 237 pp., University of Utrecht, Utrecht, Netherlands.

Jansen, J. B. H., \& Schuiling, R. D. (1976). Metamorphism on Naxos; petrology and geothermal gradients. American Journal of Science, 276(10), 1225-1253. https://doi.org/10.2475/ajs.276.10.1225

Jelinek, V. (1981). Characterization of the magmatic fabrics of rocks. Tectonophysics, 79(3-4), T63-T67. https://doi.org/10.1016/00401951(81)90110-4

Jolivet, L., \& Brun, J. P. (2010). Cenozoic geodynamic evolution of the Aegean. International Journal of Earth Sciences, 99(1), 109-138. https:// doi.org/10.1007/s00531-008-0366-4

Jolivet, L., \& Faccenna, C. (2000). Mediterranean extension and the Africa-Eurasia collision. Tectonics, 19(6), 1095-1106. https://doi.org/ 10.1029/2000TC900018

Jolivet, L., Faccenna, C., Goffé, B., Burov, E., \& Agard, P. (2003). Subduction tectonics and exhumation of high-pressure metamorphic rocks in the Mediterranean orogens. American Journal of Science, 303(5), 353-409. https://doi.org/10.2475/ajs.303.5.353

Jolivet, L., Faccenna, C., Goffé, B., Mattei, M., Rossetti, F., Brunet, C., ... Parra, T. (1998). Midcrustal shear zones in postorogenic extension: Example from the northern Tyrrhenian Sea. Journal of Geophysical Research, 103(B6), 12,123-12,160. https://doi.org/10.1029/97JB03616

Jolivet, L., Lecomte, E., Huet, B., Denèle, Y., Lacombe, O., Labrousse, L., ... Mehl, C. (2010). The north cycladic detachment system. Earth and Planetary Science Letters, 289(1-2), 87-104. https://doi.org/10.1016/j.epsl.2009.10.032

Jolivet, L., Menant, A., Sternai, P., Rabillard, A., Arbaret, L., Augier, R., ... Le Pourhiet, L. (2015). The geological signature of a slab tear below the Aegean. Tectonophysics, 659, 166-182. https://doi.org/10.1016/j.tecto.2015.08.004

Jolivet, L., Rimmelé, G., Oberhänsli, R., Goffé, B., \& Candan, O. (2004). Correlation of syn-orogenic tectonic and metamorphic events in the Cyclades, the Lycian nappes and the Menderes massif. Geodynamic implications. Bulletin de la Societe Geologique de France, 175(3), 217-238. https://doi.org/10.2113/175.3.217

Katzir, Y., Matthews, A., Garfunkel, Z., Schliestedt, M., \& Avigad, D. (1996). The tectono-metamorphic evolution of a dismembered ophiolite (Tinos, Cyclades, Greece). Geological Magazine, 133(03), 237-254. https://doi.org/10.1017/S0016756800008992

Keay, S., \& Lister, G. (2002). African provenance for the metasediments and metaigneous rocks of the Cyclades, Aegean Sea, Greece. Geology, 30(3), 235-238. https://doi.org/10.1130/0091-7613(2002)030<0235:APFTMA $>2.0 . C O ; 2$

Keay, S., Lister, G., \& Buick, I. (2001). The timing of partial melting, Barrovian metamorphism and granite intrusion in the Naxos metamorphic core complex, Cyclades, Aegean Sea, Greece. Tectonophysics, 342(3-4), 275-312. https://doi.org/10.1016/S0040-1951(01)00168-8

Ketcham, R. A. (2005). Three-dimensional grain fabric measurements using high-resolution X-ray computed tomography. Journal of Structural Geology, 27(7), 1217-1228. https://doi.org/10.1016/j.jsg.2005.02.006

Ketcham, R. A., \& Carlson, W. D. (2001). Acquisition, optimization and interpretation of X-ray computed tomographic imagery: Application to the geosciences. Computers and Geosciences, 27(4), 381-400. https://doi.org/10.1016/S0098-3004(00)00116-3

Kilian, R., Heilbronner, R., \& Stünitz, H. (2011). Quartz grain size reduction in a granitoid rock and the transition from dislocation creep to diffusion creep. Journal of Structural Geology, 33(8), 1265-1284. https://doi.org/10.1016/j.jsg.2011.05.004

Kokkalas, S., \& Aydin, A. (2013). Is there a link between faulting and magmatism in the south-central Aegean Sea? Geological Magazine, 150(02), 193-224. https://doi.org/10.1017/S0016756812000453

Koukouvelas, I. K., \& Kokkalas, S. (2003). Emplacement of the Miocene west Naxos pluton (Aegean Sea, Greece): A structural study. Geological Magazine, 140(1), 45-61. https://doi.org/10.1017/S0016756802007094

Kruckenberg, S. C., Vanderhaeghe, O., Ferré, E. C., Teyssier, C., \& Whitney, D. L. (2011). Flow of partially molten crust and the internal dynamics of a migmatite dome, Naxos, Greece. Tectonics, 30, TC3001. https://doi.org/10.1029/2010TC002751

Kruse, R., \& Stünitz, H. (1999). Deformation mechanisms and phase distribution in mafic high-temperature mylonites from the Jotun nappe, southern Norway. Tectonophysics, 303(1-4), 223-249. https://doi.org/10.1016/S0040-1951(98)00255-8

Kuhlemann, J., Frisch, W., Dunkl, I., Kázmér, M., \& Schmiedl, G. (2004). Miocene siliciclastic deposits of Naxos Island: Geodynamic and environmental implications for the evolution of the southern Aegean Sea (Greece). Geological Society of America Special Papers, 378, 51-65. https://doi.org/10.1130/0-8137-2378-7.51

Kumerics, C., Ring, U., Brichau, S., Glodny, J., \& Monié, P. (2005). The extensional Messaria shear zone and associated brittle detachment faults, Aegean Sea, Greece. Journal of the Geological Society, 162(4), 701-721. https://doi.org/10.1144/0016-764904-041

Launeau, P., Archanjo, C., Picard, D., Arbaret, L., \& Robin, P.-Y. F. (2010). Two- and three-dimensional shape fabric analysis by the intercept method in grey levels. Tectonophysics, 492(1-4), 230-239. https://doi.org/10.1016/j.tecto.2010.06.005

Launeau, P., \& Robin, P.-Y. F. (1996). Fabric analysis using the intercept method. Tectonophysics, 267(1-4), 91-119. https://doi.org/10.1016/ S0040-1951(96)00091-1

Launeau, P., \& Robin, P.-Y. F. (2005). Determination of fabric ellipsoids from measured sectional ellipses-Implementation and applications. Journal of Structural Geology, 27(12), 2223-2233. https://doi.org/10.1016/j.jsg.2005.08.003

Laurent, V., Beaudoin, A., Jolivet, L., Arbaret, L., Augier, R., Rabillard, A., \& Menant, A. (2015). Interrelations between extensional shear zones and synkinematic intrusions: The example of Ikaria Island (NE Cyclades, Greece). Tectonophysics, 651-652, 152-171. https://doi.org/ 10.1016/j.tecto.2015.03.020

Lecomte, E., Jolivet, L., Lacombe, O., Denèle, Y., Labrousse, L., \& Le Pourhiet, L. (2010). Geometry and kinematics of Mykonos detachment, Cyclades, Greece: Evidence for slip at shallow dip. Tectonics, 29, TC5012. https://doi.org/10.1029/2009TC002564

Lee, J., \& Lister, G. S. (1992). Late Miocene ductile extension and detachment faulting, Mykonos, Greece. Geology, 20(2), 121-124. https://doi. org/10.1130/0091-7613(1992)020\%3C0121:LMDEAD\%3E2.3.CO;2

Lister, G. S., \& Baldwin, S. L. (1993). Plutonism and the origin of metamorphic core complexes. Geology, 21(7), 607-610. https://doi.org/ 10.1130/0091-7613(1993)021\%3C0607:PATOOM\%3E2.3.CO;2

Lister, G. S., Banga, G., \& Feenstra, A. (1984). Metamorphic core complexes of Cordilleran type in the Cyclades, Aegean Sea, Greece. Geology, 12(4), 221-225. https://doi.org/10.1130/0091-7613(1984)12\%3C221:MCCOCT\%3E2.0.CO;2

Lister, G. S., \& Davis, G. A. (1989). The origin of metamorphic core complexes and detachment faults formed during tertiary continental extension in the northern Colorado River region, U.S.A. Journal of Structural Geology, 11(1-2), 65-94. https://doi.org/10.1016/01918141(89)90036-9 
Lloyd, G. E. (2004). Microstructural evolution in a mylonitic quartz simple shear zone: The significant roles of dauphine twinning and misorientation. In G. I. Alsop, et al. (Eds.), Flow Processes in Faults and Shear Zones, Geological Society of London Special Publications (Vol. 224, pp. 39-61).

Mainprice, D., Bachmann, F., Heilscher, R., \& Schaeben, H. (2015). Descriptive tools for the analysis of texture projects with large datasets using MTEX: Strength, symmetry and components. Geological Society of London Special Publication, 409(1), 251-271. https://doi.org/ $10.1144 /$ SP409.8

Maluski, H., Bonneau, M., \& Kienast, J. R. (1987). Dating the metamorphic events in the Cycladic area: 39Ar/40Ar data from metamorphic rocks of the island of Syros (Greece). Bulletin de la Societe Geologique de France, 8, 833-842.

McCaffrey, R. (1992). Oblique plate convergence, slip vectors, and forearc deformation. Journal of Geophysical Research, 97(B6), 8905-8915. https://doi.org/10.1029/92JB00483

Mees, F., Swennen, M., Van Geet, M., \& Jacobs, P. (2003). Applications of X-ray computed tomography on the geosciences. Geological Society of London Special Publications, 215(1), 1-6. https://doi.org/10.1144/GSL.SP.2003.215.01.01

Mehl, L., \& Hirth, G. (2008). Plagioclase preferred orientation in layered mylonites: Evolution of flow laws for the lower crust. Journal of Geophysical Research, 113, B05202. https://doi.org/10.1029/2007JB005075

Menant, A., Jolivet, L., Augier, R., \& Skarpelis, N. (2013). The North Cycladic Detachment System and associated mineralization, Mykonos, Greece: Insights on the evolution of the Aegean domain. Tectonics, 32, 433-452. https://doi.org/10.1002/tect.20037

Muto, J., Hirth, G., Heilbronner, R., \& Tullis, J. (2011). Plastic anisotropy and fabric evolution in sheared and recrystallized quartz single crystals. Journal of Geophysical Research, 116, B02206. https://doi.org/10.1029/2010JB007891

Otani, M., \& Wallis, S. (2006). Quartz lattice preferred orientation patterns and static recrystallization: Natural examples from the Ryoke belt, Japan. Geology, 34(7), 561-564. https://doi.org/10.1130/G22430.1

Paterson, S. R., Vernon, R. H., \& Tobisch, O. T. (1989). A review of criteria for the identification of magmatic and tectonic foliations in granitoids. Journal of Structural Geology, 11(3), 349-363. https://doi.org/10.1016/0191-8141(89)90074-6

Pe-Piper, G. (2000). Origin of S-type granites coeval with I-type granites in the Hellenic subduction system, Miocene of Naxos, Greece. European Journal of Mineralogy, 12(4), 859-875. https://doi.org/10.1127/ejm/12/4/0859

Pe-Piper, G., Kotopouli, C. N., \& Piper, D. J. W. (1997). Granitoid rocks of Naxos, Greece: Regional geology and petrology. Geological Journal, 32(2), 153-171. https://doi.org/10.1002/(SICI)1099-1034(199706)32:2\%3C153::AID-GJ737\%3E3.0.CO;2-1

Pitzer, K. S., \& Sterner, S. M. (1994). Equation of states valid continuously from zero to extreme pressures for $\mathrm{H}_{2} \mathrm{O}$ and $\mathrm{CO}_{2}$. Journal of Chemical Physics, 101(4), 3111-3116. https://doi.org/10.1063/1.467624

Platt, J. P., \& Behr, W. M. (2011). Lithospheric shear zones as constant stress experiments. Geology, 39(2), 127-130. https://doi.org/10.1130/ G31561.1

Platt, J. P., Behr, W. M., \& Cooper, F. J. (2015). Metamorphic core complexes: Windows into the mechanics and rheology of the crust. Journal of the Geological Society, 172(1), 9-27. https://doi.org/10.1144/jgs2014-036

Rabillard, A., Arbaret, L., Jolivet, L., Le Breton, N., Gumiaux, C., Augier, R., \& Grasemann, B. (2015). Interactions between plutonism and detachments during metamorphic core complex formation, Serifos Island (Cyclades, Greece). Tectonics, 34, 1080-1106. https://doi.org/ $10.1002 / 2014$ TC003650

Rahl, J. M., \& Skemer, P. (2016). Microstructural evolution and rheology of quartz in a mid-crustal shear zone. Tectonophysics, 680, 129-139. https://doi.org/10.1016/j.tecto.2016.05.022

Ree, J.-H. (1994). Grain boundary sliding and development of grain boundary openings in experimentally deformed octachloropropane. Journal of Structural Geology, 16(3), 403-418. https://doi.org/10.1016/0191-8141(94)90044-2

Ring, U., Glodny, J., Will, T. M., \& Thomson, S. (2010). The Hellenic subduction system: High-pressure metamorphism, exhumation, normal faulting, and large-scale extension. Annual Review of Earth and Planetary Sciences, 38(1), 45-76. https://doi.org/10.1146/annurev. earth.050708.170910

Ring, U., \& Layer, P. W. (2003). High-pressure metamorphism in the Aegean, eastern Mediterranean: Underplating and exhumation from the Late Cretaceous until the Miocene to recent above the retreating Hellenic subduction zone. Tectonics, 22(3), 1022. https://doi.org/ $10.1029 / 2001$ TC001350

Rutter, E. H., \& Brodie, K. H. (2004). Experimental intracrystalline plastic flow in hot-pressed synthetic quartzite prepared from Brazilian quartz crystals. Journal of Structural Geology, 26(2), 259-270. https://doi.org/10.1016/S0191-8141(03)00096-8

Saltikov, S. A. (1958). Stereometric metallography (2nd ed.). Moscou: Metallurgizdat.

Sanchez-Gomez, M., Avigad, D., \& Heimann, A. (2002). Geochronology of clasts in allochtonous Miocene sedimentary sequences on Mykonos and Paros Islands: Implications for back-arc extension in the Aegean Sea. Journal of the Geological Society, 159(1), 45-60. https://doi.org/ 10.1144/0016-764901031

Seward, D., Vanderhaeghe, O., Siebenaller, L., Thomson, S., Hibsch, C., Zingg, A., ... Duchene, S. (2009). Cenozoic tectonic evolution of Naxos Island through a multi-faceted approach of fission-track analysis. Geological Society of London, Special Publication, 321(1), 179-196. https:// doi.org/10.1144/SP321.9

Siebenaller, L. (2008). Circulations fluides au cours de l'effondrement d'un prisme d'accrétion crustal : L'exemple du "Metamorphic Core Complex" de l'lle de Naxos (Cyclades, Crèce), (PhD thesis). Laboratoire Géologie et Gestion des Ressources minérales et énergétiques, Université de Nancy, Vandoeuvre-lès-Nancy, France.

Skemer, P., Katayama, I., Jiang, Z., \& Karato, S. I. (2005). The misorientation index: Development of a new method for calculating the strength of lattice-preferred orientation. Tectonophysics, 411(1-4), 157-167. https://doi.org/10.1016/j.tecto.2005.08.023

Smith, S. A. F., Holdsworth, R. E., \& Collettini, C. (2011). Interactions between low-angle normal faults and plutonism in the upper crust: Insights from the island of Elba, Italy. Geological Society of America Bulletin, 123(1-2), 329-346. https://doi.org/10.1130/B30200.1

Stipp, M., Stünitz, H., Heilbronner, R., \& Schmid, S. M. (2002). The eastern Tonale fault zone: A "natural laboratory" for crystal plastic deformation of quartz over a temperature range from 250 to $700^{\circ} \mathrm{C}$. Journal of Structural Geology, 24(12), 1861-1884. https://doi.org/10.1016/ S0191-8141(02)00035-4

Stipp, M., \& Tullis, J. (2003). The recrystallized grain size piezometer for quartz. Geophysical Research Letters, 30(21), 2088. https://doi.org/ $10.1029 / 2003 G L 018444$

Stünitz, H., \& Fitzgerald, J. (1993). Deformation of granitoid at low metamorphic grade. Il: Granular flow in albite-rich mylonites. Tectonophysics, 221(3-4), 299-324. https://doi.org/10.1016/0040-1951(93)90164-F

Tikoff, B., \& Teyssier, C. (1992). Crustal-scale, en echelon "P-shear" tensional bridges: A possible solution to the batholithic room problem. Geology, 20(10), 927-930. https://doi.org/10.1130/0091-7613(1992)020\%3C0927:CSEEPS\%3E2.3.CO;2

Tommasi, A., Vauchez, A., Fernandes, L. A., \& Porcher, C. C. (1994). Magma-assisted strain localization in an orogen-parallel. Tectonics, 13(2), 421-437. https://doi.org/10.1029/93TC03319 
Tschegg, C., \& Grasemann, B. (2009). Deformation and alteration of a granodiorite during low-angle normal faulting (Serifos, Greece). Lithosphere, 1(3), 139-154. https://doi.org/10.1130/L33.1

Urai, J. L., Schuiling, R. D., \& Jansen, J. B. H. (1990). Alpine deformation on Naxos (Greece). Geological Society of London, Special Publication, 54(1), 509-522. https://doi.org/10.1144/GSL.SP.1990.054.01.47

Van Hinsbergen, D. J. J., Hafkenscheid, E., Spakman, W., Meulenkamp, J. E., \& Wortel, R. (2005). Nappe stacking resulting from subduction of oceanic and continental lithosphere below Greece. Geology, 33(4), 325-328. https://doi.org/10.1130/G20878.1

Vanderhaeghe, O. (2004). Structural development of the Naxos migmatite dome. Geological Society of America Special Papers, 380, 211-227. https://doi.org/10.1130/0-8137-2380-9.211

Vernon, R. H. (2000). Review of microstructural evidence of magmatic and solid-state flow. Visual Geosciences, 5(2), 1-23. https://doi.org/ $10.1007 / \mathrm{s} 10069-000-0002-3$

Vigneresse, J. L. (1995a). Crustal regime of deformation and ascent of granitic magma. Tectonophysics, 249(3-4), 187-202. https://doi.org/ 10.1016/0040-1951(95)00005-8

Vigneresse, J. L. (1995b). Control of granite emplacement by regional deformation. Tectonophysics, 249(3-4), 173-186. https://doi.org/ 10.1016/0040-1951(95)00004-7

Wernicke, B. P., England, P. C., Sonder, L. J., \& Christiansen, R. L. (1987). Tectonomagmatic evolution of Cenozoic extension in the North American Cordillera. Geological Society of London Special Publications, 28(1), 203-221. https://doi.org/10.1144/GSL.SP.1987.028.01.15

Wijbrans, J. R., \& McDougall, I. (1988). Metamorphic evolution of the Attic Cycladic Metamorphic Belt on Naxos (Cyclades, Greece) utilizing 40Ar/39Ar age spectrum measurements. Journal of Metamorphic Geology, 6(5), 571-594. https://doi.org/10.1111/j.1525-1314.1988. tb00441.x

Wijbrans, J. R., Schliestedt, M., \& York, D. (1990). Single grain argon laser probe dating of phengites from the blueschist to greenschist transition on Sifnos (Cyclades, Greece). Contributions to Mineralogy and Petrology, 104(5), 582-593. https://doi.org/10.1007/BF00306666 